\title{
The wage returns to on-the-job training: evidence from matched employer-employee data
}

\author{
Rita K Almeida ${ }^{1}$ and Marta Faria ${ }^{2^{*}}$
}

\author{
* Correspondence: \\ martalincefaria@gmail.com \\ ${ }^{2}$ Católica Lisbon, SBE, Lisbon, \\ Portugal \\ Full list of author information is \\ available at the end of the article
}

\begin{abstract}
Skills shortages and skill mismatch are a pressing concern for policymakers in several developing countries, and in East Asia specifically. Providing on-the-job training can be an effective policy tool to shape the skills of the existent workforce to the specific needs of the firms. This paper explores a unique data set of matched employer-employee data for Malaysia and Thailand to estimate the wage return to on-the-job training in these two countries. Exploring propensity score matching estimates, we show that the average wage returns to on-the-job training are $7.7 \%$ for Malaysia and $4.5 \%$ for Thailand. Furthermore, we find evidence that the wage returns to on-the-job training are higher for males than for females in Malaysia and that, for both countries, returns are higher for workers with at least secondary education
\end{abstract}

JEL Classification codes: J24; J30

Keywords: On-the-job training; Wages; Matched employer-employee data

\section{Introduction}

Many economists have emphasized the importance of human capital accumulation for growth (e.g. Lucas, 1988; Romer, 1990; Aghion-Howitt, 1998). Human capital accumulation is done throughout life, but more than one half of this lifetime accumulation is done on-the-job after completing formal schooling (e.g., Heckman et al., 1998). In spite of the importance, much more is known about the investment in formal schooling, and specifically on the returns to formal schooling, than on the investment in on-the-job training and their returns.

This paper explores a matched employer-employee data set with unique information on formal firms and their workers for two developing countries with very different levels of development, Malaysia and Thailand ${ }^{1}$. According to the World Economic Outlook Database from 2005, the per capita GDP in 2002 was 3,880 USD in Malaysia and 1,994 USD in Thailand and in 2004 was 4,624 USD and 2,521 USD, respectively ${ }^{2}$. Between 2002 and 2004, these economies were growing at similar rates $(5.6 \%$ and $6.1 \%)$. In terms of population, Thailand more than doubles the size of Malaysia $(65 \mathrm{~m}$ vs. $25 \mathrm{~m}$ ). Both countries present a high literacy rate of around 93\%. East Asian countries have been drawing a great deal of attention to themselves. Impressive growth rates, competitive wages and high levels of education of the workforce are just some of the reasons why it has now become so interesting to study these countries. Having

(C) 2014 Lince de Faria and Almeida; licensee Springer. This is an Open Access article distributed under the terms of the Creative Commons Attribution License (http://creativecommons.org/licenses/by/2.0), which permits unrestricted use, distribution, and reproduction in any medium, provided the original work is properly credited. 
a detailed data-set from these two countries offers the possibility of studying the dynamics of these labor markets and their investment in job training.

In developing countries, governments are increasingly concerned with the rapidly changing demand for skills and the slow response of the general and vocational schooling tracks to adjust the provision of skills. As a consequence, many employers complain about the lack of skills and education of their workforce. Policymakers are thus increasingly concerned that the supply of skills in the labor market does not keep pace with the demand. The investment by firms in on-the-job training is one important way to mitigate this skills' gap as it develops job relevant skills among the existing workforce.

The evidence on both the incidence and the economic returns to on-the-job training is generally scarce in developing countries ${ }^{3}$. And it is unclear how different the returns should be in developed and developing countries. On the one hand, the returns to the investment in job training (as well as in schooling) could be higher in developing than in developed countries simply because skilled labor is scarcer in developing countries (e.g. Psacharopoulos and Patrinos, 2004). On the other hand, if skilled labor and capital are complements, the returns to this investment could be smaller in developing countries, where capital is relatively scarce.

In theory, whether workers with and without on-the-job training receive, all else constant, significantly different wages will also relate to whether the training offered general or firm specific skills. It may also relate to whether there are differences in the competitiveness of the local labor markets. When the labor market is perfectly competitive and training is general, workers will support the cost of job training through lower wages during that same period. Once training is received, the worker will be paid the equivalent to his marginal productivity, which we now assume to be higher (e.g. Becker, 1964). But when training is firm specific the costs and benefits will likely be shared between the firm and the worker depending on the bargaining power of each one of them. In principle, the worker will receive a lower wage at the time of the training, to account for his share of the costs, and a higher wage after the training event, depending on the benefit he could extract from the firm (e.g. Leuven and Oosterbeek, 2001). If the labor market is not competitive and firms are able to pay a wage lower than the worker's marginal productivity, firms will only want to invest in training if the increase in productivity is higher than the effect in the growth rate of wages (e.g. Acemoglu and Pischke, 1999). Even in this scenario, there is no theoretical reason for the wages to decrease after the training program. They should increase or remain constant. In sum, no matter the assumptions we have, theory predicts that after participating in a training event the worker's wage should increase or stay invariable. Finally, as training is a decision variable for the firm one expects wage returns to job training to be a lower bound estimate for the impact of training in firm productivity ${ }^{4}$.

This paper estimates whether the firm's investment in job training translates into higher wages for the workers in Malaysia and in Thailand. Our findings show that the wage returns to the investment in job training decrease significantly as one controls for worker's and firm's characteristics. We find that on-the-job training is associated with increases in individual wages of $7.7 \%$ in Malaysia and $4.5 \%$ in Thailand. We also estimate that wage returns to on-the-job training tend to be quantitatively higher for men than for women although in Thailand they are not statistically significant for males. In Malaysia, the returns for males are $11 \%$ while for women they are not statistically 
different from zero. Workers that have at least completed secondary education also report higher returns to on-the-job training than other workers (returns are 9\% and 10\% for Malaysia and Thailand, respectively).

In the empirical work, we start from a simple worker level Mincer type equation relating hourly wages with several observable worker and firm characteristics, including differences in the incidence of on-the-job training. Our main coefficient of interest quantifies the average effect on wages of having received on-the-job training. However, the estimation of the effect of on-the-job training on wages poses a major challenge as training is likely to be an endogenous variable to wages. On-the-job training is a choice variable for both firms and workers and most likely is also correlated with worker and firm characteristics, which in turn are also correlated with labor productivity and wages. Failure to control in a flexible manner for these characteristics may create a bias in the estimates of the effect of training on wages, as workers selecting into training may have different characteristics. In our empirical approach, we hope to minimize this problem by exploring a rich data set with many worker and firm characteristics and the propensity score matching (PSM) method. When compared to ordinary least squares (OLS), the PSM estimates allow for a more flexible (non-linear) functional form relating observable worker characteristics and their wages.

The propensity to score matching method is developed in two steps. First, it estimates the probability of each worker to be selected into the training provided by the firm, given his or her observable characteristics. Based on this probability, it generates a "control group" of workers that did not participate in the training but whose probability of being selected into on-the-job training was very similar to the probability observed for the sample of trained individuals. These workers are very "similar" to those actually participating in training in all their observable characteristics (e.g., education, occupation in the labor market, years of experience). The only thing that distinguishes them from the trained workers is the sole fact of not having received on-the-job training. Hence, the wage difference between these two groups can be fully attributed to the wage impacts of on-the-job training.

Our empirical findings document two interesting patterns across the two countries. First, the incidence of on-the-job training differs significantly by several worker and firm characteristics. In particular, we find that the more educated and more tenured workers are, in both countries, the more likely they are to receive on-the-job training. We also show that larger, more innovative foreign firms are also more likely to invest in on-the-job training. Second, there is strong evidence that the workers' wages increase with the incidence of on-the-job training in both countries. In our preferred estimates exploring propensity score matching, the average wage returns to on-the-job training are 7.7\% in Malaysia and 4.5\% in Thailand. Furthermore, the heterogeneity analysis shows that in Malaysia the wage returns to job training are larger for men (11\%) than for women (for whom they are not statistically different from zero). We also find that in both countries there are higher wage returns to job training for workers with completed secondary education or more years of education when compared to those who have not completed secondary education. The returns to on-the-job training for workers with at least secondary education are $9 \%$ in Malaysia and $10 \%$ in Thailand, respectively. In contrast, for workers with lower levels of education, there is no evidence of positive wage impacts both for Malaysia and Thailand. These findings clearly reinforce the idea that the investment in job training is complementary to the initial level of education of workers. 
Our paper relates closely to two empirical literatures. First, it relates to the work analyzing the firm's investment in on-the-job training in developing countries (e.g., Ariga and Brunello, 2002, Almeida and Aterido, 2010, 2011, Almeida, 2010 and Almeida and Cho, 2012). The main empirical patterns found in these papers for developing countries are close to the findings found for developed countries (e.g., Bassinini et al. 2005). Larger, more open and innovative firms, with a more skilled workforce and operating in more technologically intensive sectors are more likely to train their employees. The major exception is Ariga and Brunello (2002). Exploring an employee survey for Thailand in 2001, they find a significant and negative relationship between years of formal educational and training.

Second, we relate to the empirical work quantifying the wage returns to on-the-job training exploring worker level data ${ }^{5}$. Table A1 in the Appendix summarizes some of the main empirical studies quantifying the wage returns to on-the-job training, for developing and developed countries. Panels A and B report the estimates from papers using worker level data. Panel A refers to developed countries and Panel B to developing countries ${ }^{6}$. A word of caution is needed when comparing cross country estimates of the returns to on-the-job training. First, the variable capturing on-the-job training differs significantly across data sets yielding reduced comparability across studies. Second, there is little comparability in the reduced form equation used across most of the analysis ${ }^{7}$.

The point estimates reported in Panel A for developed countries are very diverse. Some studies report positive and significant wage returns to training. However, more recently, as longitudinal data becomes available and experimental methods are used, the wage returns to on-the-job training tend to be smaller than in the cross section studies. Furthermore, in some cases, the returns are even zero (e.g., Leuven and Oosterbeek, 2002, 2004) ${ }^{8}$. The point estimates for most developing countries, reported in Panel B, are generally in the order of $20 \%$. The evidence in the panel is also quite diverse. Chung (2000) and Johanson and Wanga (2008) explore cross sectional data and find evidence of large returns (between 20\% and 38\%) for Malaysia and Tanzania, respectively. On the other hand, Frazer (2006) finds that in Ghana, during the 90s, the returns to apprenticeship training were not statistically different from zero. Monk et al. (2008) find in addition some heterogeneity within the country and across education levels. They show that the returns of apprenticeships are 50\% for individuals with no education but decline as education raises. They find evidence that the returns are zero for individuals with more than 6 years of formal education.

The methodology in our paper is closer to Rosholm et al. (2007). They estimate that the returns to training are on average $21 \%$ for Kenya and that in Zambia training is not associated with higher wages. Like us, they also explore a matched employer and employee data set (collected by the World Bank) and a propensity score matching methodology. However, the larger number of observations in our sample and the more detailed information on worker and firm characteristics allowed us to conduct a deeper analysis. First, we consider hourly wages as a dependent variable, while Rosholm et al. (2005) consider only monthly wages. Second, we are able to control both for detailed worker human capital characteristics and for several firm characteristics that they do not. At the worker level, we include variables such as having received training at a previous employer, owning a bank account and using the internet. These variables, 
especially past training, will prove to be important in explaining the selection into training. At the firm level, we are able to control for the average years of schooling of the workforce, for the degree of innovation or for the degree of exports.

The paper proceeds as follows. Section 2 describes the dataset used and the descriptive statistics. Particularly, in Section 2.1 we explain in detail our main dependent variable of interest: the logarithm of workers' hourly wages. In Section 3 we analyze which variables determine the selection into training. Section 4 presents the propensity score matching estimates for the wage returns to on-the-job training. In section 4.1, we explain the empirical model, and in section 4.2 we report the main empirical findings for the wage returns to on-the-job training. In Section 5, we report heterogeneity analysis by gender and level of education. Finally, Section 6 concludes.

\section{Data and descriptive statistics}

We explore a matched employer-employee data set collected by the World Bank, Enterprise Surveys, for Malaysia (2002) and Thailand (2004) $)^{9}$. A total of 1,152 firms were surveyed in Malaysia and 1,385 in Thailand. For each firm, a random sample of $10 \mathrm{em}-$ ployees in each firm was interviewed yielding a total of 10,822 and 13,850 firm-worker observations in Malaysia and Thailand, respectively. However, in the analysis we have excluded observations with missing values for the main covariates of interest both at the firm and worker level. As a result, the number of observations used will be 6,679 for Malaysia and to 9,418 for Thailand, respectively.

This data set has several advantages to study this topic. First, the questionnaire is similar across the two countries, which ensures comparability of the results. Second, the survey collects simultaneously detailed information on worker and firm characteristics. In particular, at the firm level it collects information on the sector of activity, geographical location $^{10}$, total number of employees, public and foreign ownership as well as information on the human capital of the manager, on the average years of formal education of the workforce, number of employees per occupation, and percentage of women in the firm. The survey also gathers information on technological variables or investments in new production technologies such as R\&D expenses, introduction of new products and adoption of new technologies. At the worker level, it collects information on gender, age, marital status and nationality. Most importantly it also collects detailed human capital characteristics like years of formal education, tenure with the firm, years of experience in the labor market, and whether each worker enrolled in vocational training programs in the past. Finally, the survey collects information on whether the firm offered on-the-job training to their employees last year and whether the employees interviewed took any formal training since they joined that firm. In addition, monthly wages and hours of work per week are also reported.

In particular, the survey contains the following information about formal training programs at the firm and at the worker level. At the firm level, the survey asks: "Did your plant run formal in-house training programs for its employees in 2001?", " Did your plant send employees to formal training programs run by other organizations during the fiscal year of 2001"? At the worker level the survey asks: "Have you received formal training since you joined this firm?". Based on these two questions, we constructed two variables capturing the incidence of on-the-job training at the firm and at the worker level. First, we constructed a firm level dummy variable that equals one if the firm 
offered formal training to its workers in the year prior to the survey. Second, we constructed a worker level dummy variable that equals one if the worker has received formal training since he joined that firm. In addition, for those workers whose the current position is not their first job, we have information on whether the worker received training at his previous job ${ }^{11}$.

Table A2 in the Appendix describes the main variables used. Tables A3 and A4 in the Appendix report summary statistics for the main firm and worker characteristics used in the paper. In Malaysia, the final sample covers manufacturing (79\%) and services (21\%). In Thailand, the sample only covers manufacturing. In addition, the distribution of firms across the two countries is different. While in Malaysia, small firms are approximately half of the sample, in Thailand, medium, large and very large firms account for more than $70 \%$ of the sample. In the two countries, approximately $70 \%$ of the firms are domestic owned and a large share exports at least some of their sales $(66 \%$ in Thailand and 62\% in Malaysia). Rubber and Plastics (22\%) and food processing (18\%) are the two more represented industries in Malaysia. In the Thai sample, firms are more equally divided among the different sectors. Finally, firms in Malaysia have a higher share of skilled labor (49\%) than in Thailand (24\%) and the average of years of formal education is also slightly higher in Malaysia than in Thailand.

Finally, Table A3 also shows that the training incidence at the firm level is $51 \%$ in Malaysia and $76 \%$ in Thailand ${ }^{12}$. The incidence of training is smaller in Malaysia in part due to the low training incidence of job training among the firms operating in Rubber and Plastics (36\% of the firms train) and in Food Processing (55\% of the firms train). Also interestingly, in Malaysia most of the firms that offer training explore both facilities in house and externally. Most of the training costs are supported directly by the firms (at least formally, as firms can transfer the cost of training to employees through lower wages). Only $6 \%$ of the firms for Malaysia and 3\% for Thailand report to have shared the costs of training with their employees ${ }^{13}$.

Table A4 in the Appendix computes summary statistics for the sample of workers in both countries. In both samples women represent approximately half of the sample. The average age, tenure and years of experience is also quite similar across the two countries. Again, the human capital of the workforce is higher in Malaysia than in Thailand. In Malaysia only 15\% of the workers have up to primary education compared with $30 \%$ of the workers in Thailand. In Malaysia there are also more workers with polytechnic or vocational education than in Thailand (15\% vs. $6 \%$ ). This higher human capital translates also into more skilled occupations in Malaysia than in Thailand in our sample. While skilled production workers is the most represented group in the Malaysian sample (36\%), in Thailand, the most represented occupation group is unskilled production workers (37\%). Also interestingly, Malaysian workers have been more exposed to foreign languages and cultures. In particular, 7\% of the Malaysian workers but less than $1 \%$ of Thai workers studied in a foreign country.

Table A4 in the Appendix also shows that the incidence of on-the-job training is higher in Thailand than in Malaysia also at the worker level. In Malaysia, 33\% of the workers report having received some training since they joined the firm. In Thailand, this number is $52 \%$ of the workforce. The percentage of workers that received training at the previous employer was $17 \%$ in Malaysia and $24 \%$ in Thailand. 


\subsection{Dependent variable}

The main dependent variable of interest is the natural logarithm of the hourly wage (in USD) ${ }^{14}$. In Table 1 we present the average log hourly wage as well as the raw difference in the average hourly wage for both trained and not trained workers.

The results in the table show that workers who report having received some formal on-the-job training since joining the firm report higher earnings than non-trainees in both countries. However, this difference in the average wages is likely capturing the effect of worker and firm characteristics that drive the selection of workers into training and that, simultaneously, also influence their hourly wages.

\section{The selection of firms and workers into training}

In order to understand which variables influence the selection into on-the-job training we run a series of regressions at the firm and worker level. We assume that firms decide whether or not to train their workers if the profits from this investment are greater than the costs:

$$
\operatorname{Train}_{j f r}= \begin{cases}1 & \text { if } \pi^{*} \\ 0 & \text { othr }>0 \\ 0 & \text { othise. }\end{cases}
$$

where $\operatorname{Train}_{j f r}$ is a dummy variable that equals one if firm $j$, operating in industry $f$ and region $r$ offered on-the-job training to its employees during the year prior to the survey and $\pi^{*}{ }_{j f r}$ are the net benefits of investing in training. Since $\pi^{*}{ }_{j f r}$ is unobservable we

Table 1 Differences in wages for workers with and without training

\begin{tabular}{|c|c|c|c|}
\hline & $\begin{array}{c}\text { Mean } \\
(1)\end{array}$ & & $\begin{array}{l}\text { SE } \\
(2)\end{array}$ \\
\hline \multicolumn{4}{|l|}{ Panel A: Malaysia } \\
\hline Avg Ln wage & 0.410 & & $(0.778)$ \\
\hline Avg Ln wage for the trained & 0.698 & & $(0.793)$ \\
\hline Avg Ln wage for the non-trained & 0.266 & & $(0.729)$ \\
\hline Difference in Avg Ln wage for the trained and the not trained & $0.431^{* * *}$ & & $(0.019)$ \\
\hline Number of workers trained & & 2,215 & \\
\hline Number of workers not trained & & 4,464 & \\
\hline Total number of workers & & 6,679 & \\
\hline \multicolumn{4}{|l|}{ Panel B: Thailand } \\
\hline Avg Ln wage & -0.135 & & $(0.715)$ \\
\hline Avg Ln wage for the trained & 0.000 & & $(0.743)$ \\
\hline Avg Ln wage for the non-trained & -0.285 & & $(0.657)$ \\
\hline Difference in Avg Ln wage for the trained and the not trained & $0.284^{* * *}$ & & $(0.014)$ \\
\hline Number of workers trained & & 4,941 & \\
\hline Number of workers not trained & & 4,477 & \\
\hline Total number of workers & & 9,418 & \\
\hline
\end{tabular}

Source: Authors' calculations based on the Enterprise Surveys (World Bank).

Note: We report the natural logarithm of hourly wage in USD at the time of the survey. * significant at $10 \%$, ** significant at $5 \%{ }^{* * *}$ significant at $1 \%$. Panel A reports the descriptive statistics for the sample of workers in Malaysia and Panel B reports the descriptive statistics for the sample of workers in Thailand. Column (1) reports the mean of the variables listed, and column (2) and reports standard errors. 
assume $\pi^{*}{ }_{j f r}$ is a function of several firm, industry and regional characteristics. We also assume that $\pi^{*}{ }_{j f r}$ is linear so that $\pi^{*}{ }_{j f r}=\delta Z_{j f r}+\mu_{f}+\mu_{r}+\varepsilon_{j f r}$, where $Z_{j f r}$ is a vector of firm characteristics and $\mu_{f}$ are industry fixed effects, $\mu_{r}$ are region fixed effects, and $\varepsilon_{j f r}$ captures unobserved firm characteristics. Given this linear form, the probability that firm $j$ offers formal on-the-job training to its employees is given by:

$$
\operatorname{Pr}\left(\operatorname{Train}_{j f r}=1\right)=\operatorname{Pr}\left(v_{j f r}>-\delta Z_{j f r}-\mu_{f}-\mu_{r}\right)
$$

Assuming that the error term $\varepsilon_{j f r}$ follows a normal distribution, equation (2) can be estimated by maximum likelihood (probit). Tables A5 and A6 in the Appendix report the estimates of different specifications of equation (2) in the text for Malaysia and Thailand, respectively. Specifications (1) through (6) differ in the observable firm characteristics that are included. In all specifications we control for two-digit ISIC industry codes and for region dummies. Specification (7), which we will consider our baseline specification of firm characteristics, includes the interaction of industry and region fixed effects. In this specification, we control for size of the firm, age, export intensity, foreign ownership, education of the workforce (including managerial education) and degree of technological adoption. The findings show that training incidence increases with firm size in both countries although not with age of the firm. Training incidence increases also with the firm's presence in external markets and with foreign ownership. For example, in Malaysia, training incidence is 56.4 percentage points higher in a firm with more than 250 employees than in a micro firm. We also find robust evidence that training incidence increases with the human capital of the workforce (measured both with years of education, skills of the workforce and by managerial education) and with the degree of technological adoption in the firm.

In Tables A7 and A8 we replicate the estimation of equation (2) with maximum likelihood (probit model) but consider on-the-job training incidence at the worker level as the dependent variable ${ }^{15}$. This analysis is a critical first step of the propensity score matching methodology. We consider several observable characteristics that likely determine the selection into training and that we can quantify with our detailed data set. We will then estimate the fitted values for each worker level observation. Therefore, for each worker who has received training it is feasible to match him/her with a worker with a close enough fitted probability. This group of workers will constitute the control group in the estimation of the impacts of on-the-job training on wages.

Specifications (1) through (5) of Tables A7 and A8 always include the baseline firm characteristics reported in column (7) of Tables A5 and A6. However, the set of worker level characteristics differs across columns. Column (1), in addition to the baseline firm characteristics, controls for the worker's education (including vocational education), gender, age, tenure with the firm, potential experience, marital status, occupation, if the worker is an apprentice and if he belongs to a trade union. In columns (2) through (5) we add dummy variables capturing if the worker has a computer at home (specification 2 ), owns a bank account (specification 3), uses regularly internet for transactions (specification 4) and has received training at a previous employer (specification 5). In Table 2, we report the results for both countries exploring our preferred specification (specification (5) in Tables A7 and A8 in the Appendix). 
Table 2 Average marginal effects and asymptotic errors from the worker level probit for participation in training

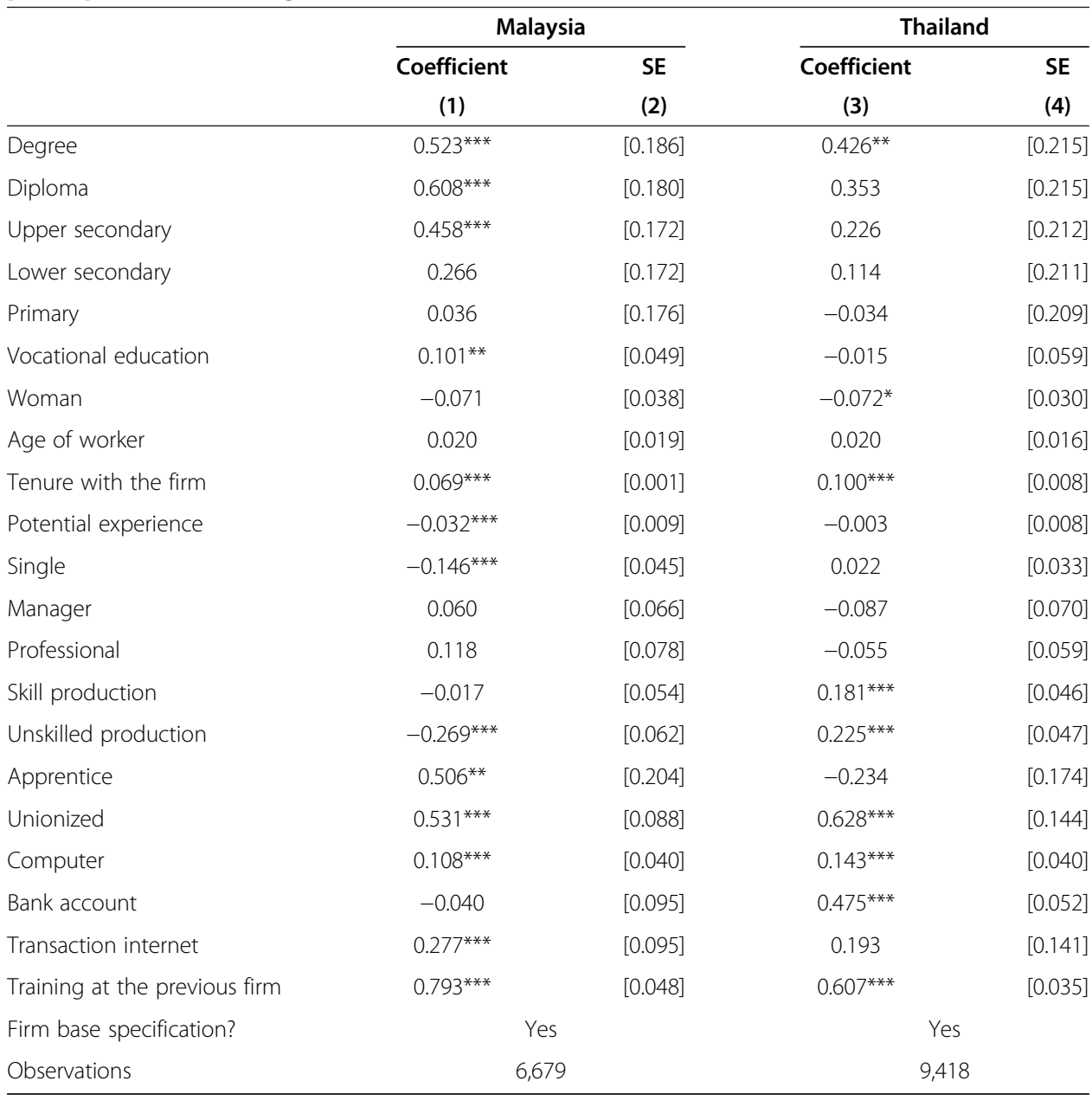

Source: Authors' calculations based on the Enterprise Surveys (World Bank).

Note: The dependent variable is a dummy variable that assumes the value 1 if the worker received any formal training after joining the firm. The table reports the marginal effects (at mean values) on the firm's propensity to train from probit regressions (equation 3 in the text). The regressions control for several firm level characteristics, as it is listed in the specification reported in column (7) of Tables A5 and A6 of the Appendix. * significant at 10\%, ${ }^{* *}$ significant at $5 \%$, *** significant at $1 \%$. Columns (1) and (3) report the coefficient of the variable, and columns (2) and (4) report standard errors. These are the same coefficients as column (5) in Tables A7 and A8 of the Appendix.

The findings show that training incidence increases with the level of human capital of the worker from secondary education onwards and, interestingly, also increases as individuals hold some degree of vocational training. Women are less likely to receive on-the-job training in Thailand but not in Malaysia. Workers with longer tenure with the firm are more likely to receive on-the-job training in both countries. Differences in the probability to participate in training are not statistically significant when comparing workers of different ages. In Thailand, training incidence is higher both for skilled and unskilled production workers than for non-production workers. In Malaysia, we only find that unskilled production workers are less likely to train than non-production workers. This might be a result driven by the industries represented in the sample ${ }^{16}$. In both countries, we find that workers that belong to a trade union and use a computer 
at home are more likely to participate in job training than others. In Malaysia, workers that have ever made a transaction through the internet also tend to be selected into training more frequently than those who have never used e-commerce. Moreover, we also find that current training incidence is very strongly and positively correlated with past training incidence for both countries.

\section{The wage returns to on-the-job training}

The accumulation of human capital has long been seen as an investment decision (Becker, 1964). While investing, each individual gives up some proportion of income during the education and training period in exchange of increased future earnings. Individuals will be willing to take additional schooling or training if the costs (tuition and training course fees, forgone earnings while at school and reduced wages during the training period) are compensated by higher future earnings. Assuming perfectly competitive labor markets, wages reflect the marginal product of workers and should increase with the accumulation of human capital if individuals become more productive in their current job ${ }^{17}$.

\subsection{Propensity score matching}

We use propensity score matching to quantify the wage returns of job training at the worker level. The main idea underneath the propensity to score matching methodology is to match as closely as possible individuals who have received training to those not receiving on-the-job training, to then be able to meaningfully compare the differences in their wages ${ }^{18}$.

Let $W_{1 i}-W_{0 i}(4)$ be the difference between a worker's log wage $W_{i}$ that results from participating in training. If worker $i$ participates in training, he gets wage $W_{1 i}$; and if he does not receive training, his wage is $W_{0 i}\left(D_{i} \in\{0,1\}\right.$ summarizes worker $i$ 's treatment, 1 and 0 mean, respectively, receiving and not receiving training). We do not observe, however, the wages of individuals who receive training if they had not received it, that is $W_{0 i}$, and we do not observe wages for the individuals who were not trained if they were trained $W_{1 i}$.

As we have argued in a previous section, to assess the impact of job training it is not enough to compute the average wage difference between the workers that received training and the ones that did not participate in training. The main reason is that most likely a large part of this difference can be caused not by training itself but also be driven by other worker and firm characteristics that determine the selection into training. The propensity to score matching (PSM) methodology departs from the assumption that all the relevant differences between the treated and the untreated individuals are captured by their observables. Within the group of the untreated it selects a group as similar as possible to the treated group. The difference in wages across workers who received training and this set of workers is a better estimate of the returns to training.

First, given the richness of our data set, we assume that a significant number of worker and firm variables $(X)$ explain the relevant differences between the treated and the untreated groups. For consistent estimations it is required that $W_{0 i} \perp D_{i} \mid X$ where $X$ is the set of observed variables ${ }^{19}$. However, if $X$ is multidimensional it becomes difficult to match the individuals. Rosenbaum and Rubin (1983) have proved that $W_{0 i} \perp D_{i} \mid X$ implies $W_{0 i} \perp D_{i} \mid p(X)$, where $p(X)$ are the propensity score fitted values, or the probability of participating in 
training. Therefore the untreated individuals that present higher probabilities of receiving training will compose the counterfactual group.

The first step of this method is thus to estimate the probability of each worker to receive on-the-job training. This is given by the fitted values of the worker level probit regressions for the incidence of training. We consider the specification reported in Table 2. There, we control for several worker (including education, gender, age, tenure with the firm, potential experience, marital status, occupation) and firm characteristics (including firm size, age, export intensity, foreign ownership, education of the workforce, degree of technological adoption). The reason why we also include firm level characteristics is to control for the fact that the training decision depends partly on the firm. By matching workers with similar characteristics and who work for similar firms we hope to minimize the selection bias that is likely arising from the fact that individuals selected into training may be the ones with higher unobserved ability.

Because the treated individual $i$ can be matched with one or $n$ individuals on the non-treated group, we choose the one-to- $n$ matching method. This implies that each individual in the "treatment" group is matched with a weighted average of all individuals in the "control" group that have similar fitted values ${ }^{20}$. After associating each treated individual $i$ with a mean of untreated individuals with different weights we simply compute the difference between the averages of the log wages in the treated group and in the control "weighted average" to quantify the causal effect of on-the-job training on wages.

In Malaysia there is a set of 4,425 untreated individuals and 2,202 treated (a total support group of 6,627). In Thailand, the set of untreated and treated groups have 4,477 and 4,941 individuals, respectively (9,418 individuals in total). We compute the average treatment effect on the treated individuals (ATT), yielding the impact of the training on the set of workers who actually end up receiving it. Table A11, in the Appendix, reports the balancing tests to check the quality of the matching methodology to our sample. It is reassuring to see statistically similar means in most of the covariates for both the treated and the control groups. The only exception is the variable tenure in Malaysia for which the t-statistic rejects the null hypothesis.

\subsection{Empirical results for the returns to training}

As mentioned above workers selected into training may receive on average different wages than those not selected. In this section, we present estimates of the average treatment effect on the treated (ATT), which is the effect of the training (received since joining the firm) on the hourly log wages of trained workers. We report both the raw log wage differences and the ATT using propensity score matching. Table 3 reports that the raw difference in wages between the treated and the untreated groups is $42.9 \%$ for Malaysia and $28.4 \%$ for Thailand. Once we explore the propensity to score matching methodology, we find that the impact of on-the-job training on hourly wages falls to $7.7 \%$ for Malaysia and $4.5 \%$ for Thailand, respectively. The estimates are significant at a $5 \%$ level of confidence for both countries.

Therefore, Malaysia presents higher returns from job training than Thailand. A priori, this is not immediate. On the one hand, Malaysia has a higher per capita gross domestic product and also has more youth in schools than Thailand, suggesting that their returns to human capital could be smaller than in Thailand. On the other hand, the accumulated stock of capital in Malaysia is higher, and if skills and capital are 
Table 3 Wage returns to on-the-job training

\begin{tabular}{lccc}
\hline & $\begin{array}{c}\text { Difference in log wages } \\
\text { (1) }\end{array}$ & SE & t-stat \\
\hline Panel A: Malaysia & $0.429^{* * *}$ & (2) & \\
Unmatched & $0.077^{* * *}$ & 0.02 & 21.9 \\
ATT & 4,425 & 0.03 & 2.92 \\
Untreated & 2,202 & & \\
Treated & 6,627 & & 15.46 \\
Sample size & & & 2.37 \\
Panel B: Thailand & $0.284^{* * *}$ & 0.02 \\
Unmatched & $0.045^{* *}$ & 0.02 & \\
ATT & 4,477 & & \\
Untreated & 4,941 & & \\
Treated & 9,418 & & \\
Sample size & & & \\
\hline
\end{tabular}

Source: Authors' calculations based on the Enterprise Surveys (World Bank).

Note: ${ }^{*}$ significant at $10 \%,{ }^{* *}$ significant at $5 \%,{ }^{* *}$ significant at $1 \%$. The table explores the propensity score matching estimate of equation (4) in the text. Panel A reports the PSM results for the sample of workers in Malaysia, and Panel B reports the results for the sample of workers in Thailand. Column (1) reports the Average Treatment Effect on the Treated (ATT). The estimate gives the impact on wages of training for those actually participating in training. Column (2) reports standard errors and column (3) reports the t-statistic.

complementary, all else constant, the returns to human capital could be higher than in Thailand. Also if training presents decreasing returns, it is reassuring to see that returns are lower in the country with the highest training incidence: Thailand.

For comparability, in Tables A9 and A10 in the Appendix, we show the estimates for the impact of training on wages, using the least squares methodology (OLS) and considering alternative specifications. The specification that is closer to the variables we control in the PSM estimates is reported in column (3). Comparing columns (1) and (3) in Tables A9 and A10, we see that the wage difference between trainees and nontrainees falls from $43.1 \%$ to $4.3 \%$ in Malaysia and from $28.4 \%$ to $4.2 \%$ in Thailand. Even though the numbers are very similar for Thailand and for Malaysia, the OLS estimates are lower than the PSM estimates, suggesting that least squares estimates have a downward bias.

\section{Heterogeneity analysis}

Until now we assumed that returns to on-the-job training are the same for all the workers and firms within each country. In this section, we allow for the returns to be different by two fundamental worker characteristics: gender and education. Our results show that the returns to training are higher for men than for women in Malaysia, and for workers with completed secondary education or more education in both countries, when compared with workers that have not completed secondary education.

Table 4 reports the main results for the sample of men and women, separately. Panel A reports the results for Malaysia, while Panel B reports the results for Thailand. Table 4 shows that, in Malaysia, wage returns are higher for men than for women. Men present wage returns to on-the-job training of $11 \%$, while there are no statistically significant 
Table 4 Wage returns to on-the-job training, by gender

\begin{tabular}{|c|c|c|c|c|c|c|}
\hline & \multicolumn{3}{|c|}{ Sample of men } & \multicolumn{3}{|c|}{ Sample of women } \\
\hline & $\begin{array}{l}\text { Difference in log wages } \\
\text { (1) }\end{array}$ & $\begin{array}{l}\text { SE } \\
(2)\end{array}$ & $\begin{array}{l}\text { t-stat } \\
(3)\end{array}$ & $\begin{array}{c}\text { Difference in log wages } \\
\text { (4) }\end{array}$ & $\begin{array}{l}\text { SE } \\
(5)\end{array}$ & $\begin{array}{c}\text { t-stat } \\
(6)\end{array}$ \\
\hline \multicolumn{7}{|c|}{ Panel A: Malaysia } \\
\hline ATT & $0.11^{* * *}$ & 0.04 & 2.95 & 0.05 & 0.04 & 1.30 \\
\hline Untreated & 2,394 & & & 2,035 & & \\
\hline Treated & 1,269 & & & 933 & & \\
\hline Observations & 3,663 & & & 2,968 & & \\
\hline \multicolumn{7}{|c|}{ Panel B: Thailand } \\
\hline ATT & 0.05 & 0.03 & 1.44 & $0.04^{*}$ & 0.02 & 1.81 \\
\hline Untreated & 1,970 & & & 2,507 & & \\
\hline Treated & 2,182 & & & 2,759 & & \\
\hline Observations & 3,663 & & & 5,266 & & \\
\hline
\end{tabular}

Source: Authors' calculations based on the Enterprise Surveys (World Bank).

Note: * significant at $10 \%$, ** significant at $5 \%$, *** significant at $1 \%$. The table uses propensity score matching to estimate equation (4) in the text. We estimate separate regressions by gender. Columns (1) and (4) report Average Treatment Effect on the Treated (ATT) which evaluates the wage impact of training for those actually participating in training. Columns (2) and (5) report standard errors. Columns (3) and (6) report the t-statistic. Treated individuals are those who have participated in training and the untreated individuals are the "control group" that is similar for all characteristics to the treated group except for the fact of receiving training. Panel A reports the estimates for the sample of workers in Malaysia, and Panel B reports the estimates for the sample of workers in Thailand.

returns for women. This may be explained by the fact that women tend to go into and out of the job market more frequently than men and thus may be less likely to receive on-thejob training. This higher turnover may also make it difficult to appropriate the returns from the investments in job training. We do not find, however, that same result for Thailand. There the wage returns to job training are quantitatively larger for men than for women, although for men they are not statistically different from zero (at a 10\% level).

Table 5 reports the estimates for the samples of workers that have completed at least secondary education and for the sample of workers with less education. Panel A shows the results for Malaysia, and Panel B shows the results for Thailand. Consistent also with the findings of others in the literature, we show that the returns to on-the-job training are higher for workers that have completed at least secondary education than for workers with less education. Workers with completed secondary education have returns to training of $9 \%$ in Malaysia and of $10 \%$ in Thailand. In contrast, for those workers without completed secondary schooling, there are no statistically significant returns to on-the-job training in both countries.

\section{Conclusion}

In developing countries, governments are increasingly concerned with the rapidly changing demand for skills and the slow response of the general and vocational schooling tracks. As a consequence, many employers complain about the lack of skills and education of their workforce. Policymakers are thus increasingly concerned that the supply of skills in the market does not keep pace with the demand and think about the design of policies to address this problem. The investment in on-the-job training is one important way to mitigate this gap by developing job relevant skills among the workforce. 
Table 5 Estimated wage returns to job training, by level of education

\begin{tabular}{|c|c|c|c|c|c|c|}
\hline & \multicolumn{3}{|c|}{$\begin{array}{l}\text { Workers completed secondary education } \\
\text { or more years of schooling }\end{array}$} & \multicolumn{3}{|c|}{$\begin{array}{l}\text { Workers with up to incomplete } \\
\text { secondary education }\end{array}$} \\
\hline & $\begin{array}{l}\text { Difference in log wages } \\
\text { (1) }\end{array}$ & $\begin{array}{l}\text { SE } \\
(2)\end{array}$ & $\begin{array}{l}\text { t-stat } \\
\text { (3) }\end{array}$ & $\begin{array}{l}\text { Difference in log wages } \\
\text { (4) }\end{array}$ & $\begin{array}{l}\text { SE } \\
(5)\end{array}$ & $\begin{array}{l}\text { t-stat } \\
\text { (6) }\end{array}$ \\
\hline \multicolumn{7}{|c|}{ Panel A: Malaysia } \\
\hline ATT & $0.09^{* * *}$ & 0.03 & 2.61 & 0.05 & 0.04 & 1.11 \\
\hline Untreated & 2,075 & & & 2,242 & & \\
\hline Treated & 1,642 & & & 548 & & \\
\hline Observations & 3,717 & & & 2,790 & & \\
\hline \multicolumn{7}{|c|}{ Panel B: Thailand } \\
\hline ATT & $0.10^{* *}$ & 0.04 & 2.51 & 0.03 & 0.02 & 1.50 \\
\hline Untreated & 1,016 & & & 3,431 & & \\
\hline Treated & 1,935 & & & 2,992 & & \\
\hline Observations & 2,951 & & & 6,423 & & \\
\hline
\end{tabular}

Source: Authors' calculations based on the Enterprise Surveys (World Bank).

Note: ${ }^{*}$ significant at $10 \%,{ }^{* *}$ significant at $5 \%,{ }^{* *}$ significant at $1 \%$. The table uses propensity score matching to estimate equation (4) in the text. We estimate separate regressions by education group. Columns (1) to (3) refer to the sample of workers that have completed secondary education or more. Columns (4) through (6) refer to workers with lower levels of education (that is those with up to incomplete secondary education). Columns (1) and (4) report ATT (Average Treatment Effect on the Treated), it evaluates the wage impact of training for those actually participating in training. Columns (2) and (5) report standard errors, and columns (3) and (6) report the t-statistic. Treated individuals are those who have participated in training, and the untreated individuals are the "control group" that is similar for all characteristics to the treated group except for the fact of receiving training. Panel A reports the estimates for the sample of workers in Malaysia, and Panel B reports the estimates for the sample of workers in Thailand.

The evidence on this topic is generally scarce for developing countries. The measurement of returns to training presents several challenges, and this is the reason why we find so different results in the literature. Variables are usually not comparable across studies, and sometimes data-sets do not allow for an accurate estimation of the results.

In this paper we quantify the wage returns from on-the-job training in Malaysia and in Thailand exploring a unique data set matching workers and firms. Using a matching estimators method to control for the selection bias we find returns of $7.7 \%$ and $4.5 \%$ for Malaysia and Thailand, respectively. In Malaysia, we find that returns are clearly higher for men than for women. Workers that have completed secondary education or more also show higher wage returns than those who have not completed secondary schooling. Economic theory tells us that the wage effects are a lower bound estimate for the effect of training in productivity. Therefore the productivity impact of training in these countries should be even higher than the estimated values.

\section{Endnotes}

${ }^{1}$ We will explore the Enterprise Surveys collected by the World Bank. In each country the survey inquires whether the firms invested in formal on-the-job training programs. This paper restricts the attention to employer provided formal on-the-job training programs. It will not address informal job relevant training. Johanson and Wanga (2008) present evidence for wage returns to training in the informal sector. Kahyarara and Teal (2008) discuss the link between other types of training and labor 
market outcomes by examining the wage returns to vocational training. Fitzenberger et al. Völter (2007) study the effects of public training in helping the transitions between unemployment and employment, and Frazer (2005) studies the effectiveness of training for the self-employed in developing countries.

${ }^{2}$ These figures mean that Thailand presents a per capita GDP similar to countries such as Peru, El Salvador and Tunisia whereas Malaysia is closer to countries like Latvia Lithuania and Chile.

${ }^{3}$ See Panel B of Table A1 in the Appendix for a summary of the papers that have analyzed wage returns to training in developing countries.

${ }^{4}$ There are some empirical papers that use firm level data to try evaluate the impact of offered training on the firms' productivity (e.g. Almeida and Carneiro 2008; Barret and O'Connell 1999) and on average wages (Lopez-Acevedo and Tan 2003).

${ }^{5} \mathrm{Few}$ empirical papers have looked at the extent to which the benefits of training (ultimately effects on higher firm productivity) are shared with workers. One exception is Dearden et al. (2006) for the UK.

${ }^{6}$ Panels $\mathrm{C}$ and D summarize the works using firm and industry level data.

${ }^{7}$ For example, some papers have defined training incidence with a dummy variable capturing whether training was offered over the previous year to the survey. Others, like Bassinini et al. (2005) use the accumulated stock of training hours over the sample period (6 years). Moreover, the reduced form estimated typically depends on the data available, which in turn differs across data sets and countries. For a similar point see Haelermans and Borghans (2012).

${ }^{8}$ Leuven and Oosterbeek $(2002,2004)$ use two different methods to estimate the returns to training in Holland. Leuven and Oosterbeek (2002) identify individuals planning to enroll in a training program but did not do so due to a random event and find evidence of no returns to job training. Leuven and Oosterbeek (2004) explore a discontinuity which allowed firms to reduce their training expenses only for workers more than 40 years old Although their results are just valid locally, they also conclude that there were no returns from the investment in job training. Similarly, Sousounis (2009) explores longitudinal data and does not find evidence that training increases wages in the U.K. between 1998 and 2005.

${ }^{9}$ The information collected in the Enterprise Surveys is based on one to two hour interviews with the firm manager. This data set has been used for studying this and other topics (see e.g. Almeida and Aterido, 2011, Almeida and Carneiro, 2008a, Almeida and Fernandes, 2008). Previous versions of this project within the World Bank include the Regional Program on Enterprise Development collecting firm and worker level data in Sub-Saharan Africa countries for a decade (e.g., Rosholm et al. 2007, Frazer 2006) and the World Business Environment Survey.

${ }^{10}$ In the Malaysian sample we have firms from the Central Region: Selangor, KL, Melaka (4,641 observations); the North Region: Penang, Kedah (1,899 observations); the South Region: Johor (3,290 observations); the East Coast: Terengganu (181 observations); the Northeast (320 observations) and the South (390 observations). In Thailand firms in the sample operate in the North (730 observations); the Centre (3,260 observations); Bangkok and Vicinity (6,160 observations); the East (1,920 observations); the Northeast (320 observations) and the South (390 observations).

${ }^{11}$ The survey asks: "Did you receive formal training at the previous employer?" 
${ }^{12}$ This difference is not driven by the manufacturing/services balance in our sample. The training incidence in Malaysia is $49 \%$ only for the manufacturing sector.

${ }^{13}$ In particular, firms are asked "Did the employees share the cost of training?"

${ }^{14}$ We report log hourly wages in USD in 2002 prices for Malaysia and 2004 prices for Thailand.

${ }^{15} \mathrm{We}$ assume that a firm offers formal training to a worker if there is a net positive benefit of this investment. The main difference is that now the benefits should also be a function of the worker level observable characteristics, captured by $X_{i j f r}$. In this case, the probability of a worker $i$ being employed in firm $j$ is determined by his characteristics $\left(X_{i j f r}\right)$ and the firm characteristics $\left(Z_{i f r}\right)$ so that $\operatorname{Pr}\left(\operatorname{Train}_{i j f r}=1\right)=$ $\operatorname{Pr}\left(v_{i j f r}>X_{i j f r}-\delta Z_{i f r}-\mu_{f}-\mu_{r}\right)(3)$.

${ }^{16}$ As explained in section 2 of the text our sample only includes formal manufacturing firms.

${ }^{17}$ With imperfect competition wages do not necessarily reflect labor productivity and therefore might not reflect changes in the worker's productivity.

${ }^{18}$ For another application of this method see Rosholm et al. (2007), and for a complete theoretical discussion of the matching estimators see Heckman et al. (1999).

${ }^{19}$ This is defined, in the econometric literature, as Conditional Independence Assumption (CIA).

${ }^{20} \mathrm{~A}$ normal kernel is used to define the weights.

${ }^{21}$ The worker variables included were: educational attainment, gender, age, tenure in the firm, years of labor market experience, marital status, occupation, whether the individual is member of a labor union, owns a computer, a bank account, has ever made an internet transaction and whether the worker received training at a previous employer.

${ }^{22}$ In addition to the worker variables we described in the previous footnote we include the following firm characteristics: size, foreign capital participation, exports, average years of education of the work force, education of the manager, introduction of new production technologies, industry and region.

${ }^{23}$ Tables A9 and A10, in the Appendix, report the results for the worker variables included in the regressions. We focus on the findings in column (3). The estimates show that, in both countries, the returns to schooling are increasing with the level of formal education completed. Women and unionized workers earn lower wages than men and non-unionized workers. Wages also tend to increase with age, tenure and experience. Moreover, wages for managers and professionals are higher than the wages of nonproduction workers (omitted occupation group) and skilled production, unskilled production in both countries. Finally, those that report having a computer at home, a bank account, and using the internet regularly also report higher wages. The same happens for those individuals reporting having received training with their previous employer. Perhaps surprisingly, in Malaysia, we find that returns from past training are higher than returns from more recent training events ( $6.8 \%$ vs. $4.3 \%)$, as we expect training to depreciate with time.

\section{Appendix}


Table A1 Review of the literature on wage returns of job training

\section{Panel A: Papers using worker level data - developed countries}

\begin{tabular}{llll}
\hline Name of study & $\begin{array}{l}\text { Data, country and } \\
\text { time period }\end{array}$ & Dependent variable Training & Other independent variables
\end{tabular}

Bassinini, Booth, Worker Level Data for log hourly wage Brunello, De Paola Europe (1995-2001)

and Leuven (2005)

Albert, Serrano, Worker Level Data for log hourly wage Hernanz (2010) Europe (1995-2001)

Budría and Pereira Worker Level Data for log hourly wage (2004) Portugal (1998-2000)

Dearden, Reed Worker Level Data for log hourly wage and Reenen (2006) U.K. (1992,1997)

Leuven and Worker Level Data for log hourly wage Oosterbeek (2002) Holland (2001)

Leuven and Worker Level Data for log hourly wage Oosterbeek (2004) Holland (1999) sum over the sample period age, gender, marital status,

(6 years) of training events schooling, year, country and industry.

dummy: having participated in training between January of the previous year and the date of the interview

dummy: having ever participated in training

gender, educational attainment, potential labour market experience, firm size, industry affiliation, working time, occupation, seniority

age, experience, schooling (and interactions between these variables and training), part time, tenure, sector, firm size.

dummies: having participated in training in the for no qualifications, firm size, previews 4, 3, 2, and industry.

dummy: having participated age, gender, schooling, firm size. in training in the previous 12 months

dummy: having participated age, schooling, tenure, firm size. in training in the previous 12 in training in the previous 12 months
Effects training on Controls endogeneity training

Between 3.7\% and

$21.6 \%$ depending on

the country.

Positive for OLS but Yes

not statistically

significant for FE. Fixed effects

$12 \%$ for men and Yes

$37 \%$ for women

Excluded instruments (selection model): having a second activity and having lived abroad.

$0.15 \%$ (production $\quad$ No

sector only)

Not statistically different from zero

Yes

Randomization: control group composed by people that were planning to engage in a training activity by did not because of some random event.

Not statistically different from zero (for 40-year-old Yes workers)

They use the RD data design method.

They explore the discontinuity introduced by a new tax law that allows tax deduction for firms' expenditures on training for workers with more than 40 years. So the decision of training workers around age 40 suffers and will be influenced by an exogenous effect (the law). 
Table A1 Review of the literature on wage returns of job training (Continued)

\begin{tabular}{|c|c|c|c|c|c|c|}
\hline $\begin{array}{l}\text { Lillard and Tan } \\
\text { (1986) }\end{array}$ & $\begin{array}{l}\text { Worker Level Data for } \\
\text { U.S.A. (1983) }\end{array}$ & log annual wage & $\begin{array}{l}\text { dummies: having } \\
\text { participated in training } \\
\text { (formal and informal) in the } \\
\text { current job }\end{array}$ & $\begin{array}{l}\text { experience, schooling, tenure, } \\
\text { union member, dummy for non- } \\
\text { white, tenure, region, long run } \\
\text { state unemployment rate, cyclical } \\
\text { sensitivity of state } \\
\text { unemployment. }\end{array}$ & $\begin{array}{l}22 \% \text { for formal } \\
\text { training }\end{array}$ & No \\
\hline \multirow[t]{2}{*}{ Sousounis (2009) } & \multirow{2}{*}{$\begin{array}{l}\text { Worker Level Data for } \\
\text { U.K. (1998-2005) }\end{array}$} & \multirow[t]{2}{*}{ log weekly wage } & \multirow{2}{*}{$\begin{array}{l}\text { dummy: having participated } \\
\text { in training in the previous } 12 \\
\text { months }\end{array}$} & \multirow[b]{2}{*}{$\begin{array}{l}\text { age, gender, marital status, } \\
\text { dummy for having children with } \\
\text { less than } 12 \text { years in the } \\
\text { household, race, schooling, } \\
\text { dummies for having changed job, } \\
\text { private sector, part time } \\
\text { managerial position, supervisor, } \\
\text { firm size, region and time. }\end{array}$} & \multirow{2}{*}{$\begin{array}{l}\text { Negative }(-3 \% \text { for } \\
\text { OLS) but not } \\
\text { statistically significant } \\
\text { for FE. }\end{array}$} & Yes \\
\hline & & & & & & Fixed effects \\
\hline
\end{tabular}

\section{Panel B:Papers using worker level data - developing countries}

\begin{tabular}{|c|c|c|c|c|c|c|}
\hline Name of study & $\begin{array}{l}\text { Country and time } \\
\text { period }\end{array}$ & Dependent variable & Training & Other independent variables & $\begin{array}{l}\text { Effects training on } \\
\text { wages }\end{array}$ & Controls endogeneity training \\
\hline \multirow[t]{2}{*}{ Chung (2000) } & \multirow{2}{*}{$\begin{array}{l}\text { Worker Level Data for } \\
\text { Malaysia }(1976,1988)\end{array}$} & \multirow[t]{2}{*}{ log hourly wage } & \multirow{2}{*}{$\begin{array}{l}\text { dummy: having ever } \\
\text { participated in training }\end{array}$} & \multirow{2}{*}{$\begin{array}{l}\text { age, marital status, nationality, } \\
\text { schooling, dummies for } \\
\text { employers and unpaid family } \\
\text { workers. }\end{array}$} & \multirow{2}{*}{$\begin{array}{l}20 \%-30 \% \text { (for } \\
\text { women) }\end{array}$} & Yes \\
\hline & & & & & & $\begin{array}{l}\text { Excluded instruments (selection model): } \\
\text { having a bank account, level of education } \\
\text { in 1976, and parents occupational status. }\end{array}$ \\
\hline Frazer (2006) & $\begin{array}{l}\text { Worker Level Data for } \\
\text { Ghana (1991-1999) }\end{array}$ & log hourly wage & $\begin{array}{l}\text { dummy: having participated } \\
\text { in an apprenticeship }\end{array}$ & $\begin{array}{l}\text { gender, potential experience, } \\
\text { schooling. }\end{array}$ & $\begin{array}{l}\text { Not statistically } \\
\text { different from zero } \\
\text { for the whole sample } \\
\text { but } 17 \% \text { for self- } \\
\text { employed. }\end{array}$ & No \\
\hline $\begin{array}{l}\text { Johanson and } \\
\text { Wanga (2008) }\end{array}$ & $\begin{array}{l}\text { Worker Level Data for } \\
\text { Tanzania (2006) }\end{array}$ & log hourly wage & $\begin{array}{l}\text { dummy: having ever } \\
\text { participated in training (per } \\
\text { type: on-the-job, informal ap- } \\
\text { prenticeship, vocational, col- } \\
\text { lege/advanced) }\end{array}$ & $\begin{array}{l}\text { experience, gender, occupation, } \\
\text { schooling, rural dummy and } \\
\text { region. }\end{array}$ & $\begin{array}{l}38 \% \text { for on-the-job } \\
\text { training, } 27 \% \text { for for- } \\
\text { mal apprenticeship, } \\
47 \% \text { for vocational } \\
\text { training and } 77 \% \text { for } \\
\text { college certificated } \\
\text { training. }\end{array}$ & No \\
\hline
\end{tabular}




\begin{tabular}{|c|c|c|c|c|c|c|}
\hline $\begin{array}{l}\text { Kahyarara and Teal } \\
\text { (2008) }\end{array}$ & $\begin{array}{l}\text { Worker Level Data for } \\
\text { Tanzania (1997-2000) }\end{array}$ & log monthly wage & $\begin{array}{l}\text { dummies: current and past } \\
\text { on-the-job training and go- } \\
\text { ing on a short training } \\
\text { course in the previews six } \\
\text { months }\end{array}$ & $\begin{array}{l}\text { gender, potential experience, } \\
\text { occupation, schooling, tenure, } \\
\text { dummy for capital city, firm fixed } \\
\text { effects. }\end{array}$ & $\begin{array}{l}22 \% \text { for current on- } \\
\text { the-job training, not } \\
\text { statistically different } \\
\text { from zero for past } \\
\text { on-the-job training } \\
\text { and } 17 \% \text { for short } \\
\text { training courses. }\end{array}$ & No \\
\hline \multirow{2}{*}{$\begin{array}{l}\text { Monk, Sandefur } \\
\text { and Teal (2008) }\end{array}$} & \multirow{2}{*}{$\begin{array}{l}\text { Worker Level Data for } \\
\text { Ghana }(1984,2000)\end{array}$} & \multirow{2}{*}{ log monthly wage } & \multirow{2}{*}{$\begin{array}{l}\text { dummy: having participated } \\
\text { in an apprenticeship }\end{array}$} & \multirow{2}{*}{$\begin{array}{l}\text { gender, potential experience, } \\
\text { schooling, log hours worked per } \\
\text { week, IQ score, interaction } \\
\text { between apprenticeship and } \\
\text { schooling, city. }\end{array}$} & \multirow{2}{*}{$\begin{array}{l}50 \% \text { for people with } \\
\text { no formal education. } \\
\text { The return declines } \\
\text { as education rises. }\end{array}$} & Yes \\
\hline & & & & & & $\begin{array}{l}\text { Members of the household that also } \\
\text { made an apprenticeship, dummy for } \\
\text { household access to credit, and a } \\
\text { dummy for having internal piped water } \\
\text { in the house as a wealth indicator. }\end{array}$ \\
\hline \multirow{2}{*}{$\begin{array}{l}\text { Rosholm, Nielsen, } \\
\text { Debalen (2007) }\end{array}$} & \multirow{2}{*}{$\begin{array}{l}\text { Matched employer- } \\
\text { employee data for } \\
\text { Kenya and Zambia } \\
\text { (1995) }\end{array}$} & \multirow[t]{2}{*}{ log monthly wage } & \multirow{2}{*}{$\begin{array}{l}\text { dummy: having participated } \\
\text { in training in the previous } 12 \\
\text { months }\end{array}$} & \multirow[b]{2}{*}{$\begin{array}{l}\text { age, ethnicity, experience, gender, } \\
\text { occupation, schooling, tenure, } \\
\text { union participation and familiar } \\
\text { relations within the owners of the } \\
\text { firm, ownership, industry, location, } \\
\text { size, financial situation, skill } \\
\text { demand, turnover, unionization, } \\
\text { training annual expenses. }\end{array}$} & \multirow[b]{2}{*}{$\begin{array}{l}2.3 \% \text { for Kenya and } \\
\text { not statistically } \\
\text { different from zero } \\
\text { for Zambia. }\end{array}$} & Yes \\
\hline & & & & & & $\begin{array}{l}\text { Matching Estimators Method (Local } \\
\text { Linear Matching) }\end{array}$ \\
\hline \multirow[t]{2}{*}{ Almeida, Faria } & \multirow{2}{*}{$\begin{array}{l}\text { Matched employer- } \\
\text { employee data for } \\
\text { Malaysia (2002) and } \\
\text { Thailand (2004) }\end{array}$} & \multirow[t]{2}{*}{ log hourly wage } & \multirow{2}{*}{$\begin{array}{l}\text { dummy: having received } \\
\text { formal on the job training } \\
\text { since having joined the firm }\end{array}$} & \multirow[b]{2}{*}{$\begin{array}{l}\text { educational attainment, gender, } \\
\text { age, tenure, experience, marital } \\
\text { status, occupation, union } \\
\text { participation, computer, bank } \\
\text { account, internet transaction, } \\
\text { training at a previous employer, } \\
\text { size, foreign capital, exports, } \\
\text { education of the work force, } \\
\text { education of the manager, new } \\
\text { production technologies, industry, } \\
\text { region. }\end{array}$} & \multirow{2}{*}{$\begin{array}{l}7.7 \% \text { for Malysia and } \\
4.5 \% \text { for Thailand. }\end{array}$} & Yes \\
\hline & & & & & & $\begin{array}{l}\text { Matching Estimators Method (Local } \\
\text { Linear Matching) }\end{array}$ \\
\hline
\end{tabular}


Table A1 Review of the literature on wage returns of job training (Continued)

\begin{tabular}{|c|c|c|c|c|c|c|}
\hline \multicolumn{7}{|c|}{ Panel C: Papers using firm level data } \\
\hline Name of study & $\begin{array}{l}\text { Data, country and } \\
\text { time period }\end{array}$ & Dependent variable & Training & Other independent variables & $\begin{array}{l}\text { Effects training on } \\
\text { wages }\end{array}$ & Controls endogeneity training \\
\hline \multirow{2}{*}{$\begin{array}{l}\text { Almeida and } \\
\text { Carneiro (2008) }\end{array}$} & \multirow{2}{*}{$\begin{array}{l}\text { Firm Level Data for } \\
\text { Portugal (1995-1999) }\end{array}$} & \multirow{2}{*}{$\begin{array}{l}\text { log value added per } \\
\text { employee }\end{array}$} & \multirow{2}{*}{$\begin{array}{l}\text { average number of hours of } \\
\text { training per employee }\end{array}$} & \multirow{2}{*}{$\begin{array}{l}\text { log employees, log capital stock, } \\
\text { share occupation group, share } \\
\text { low educated workers, share } \\
\text { males workforce, cubic } \\
\text { polynomial on average wage } \\
\text { workforce, year dummies, region } \\
\text { and sector }\end{array}$} & \multirow{2}{*}{$\begin{array}{l}24 \% \text { for firms } \\
\text { providing training. }\end{array}$} & Yes \\
\hline & & & & & & $\begin{array}{l}\text { First differences, GMM: past level of } \\
\text { training as a instrument for current } \\
\text { training. }\end{array}$ \\
\hline \multirow{2}{*}{$\begin{array}{l}\text { Barrett and } \\
\text { O'Connel (1999) }\end{array}$} & \multirow{2}{*}{$\begin{array}{l}\text { Firm Level Data for } \\
\text { Ireland }(1993,1995)\end{array}$} & \multirow{2}{*}{$\begin{array}{l}\text { productivity (out-put } \\
\text { divided by total } \\
\text { employment) } \\
\text { growth }\end{array}$} & \multirow{2}{*}{$\begin{array}{l}\text { average training days per } \\
\text { worker }\end{array}$} & \multirow{2}{*}{$\begin{array}{l}\text { investment, change on } \\
\text { employment, sector, size, } \\
\text { innovation, restructuring, } \\
\text { management quality, dummies } \\
\text { for labor incentives strategies. }\end{array}$} & \multirow{2}{*}{$\begin{array}{l}\text { Increasing one day of } \\
\text { training per worker } \\
\text { increases productivity } \\
\text { growth by } 0.03 \% \text {. }\end{array}$} & Yes \\
\hline & & & & & & $\begin{array}{l}\text { Dependent variable is productivity } \\
\text { growth }\end{array}$ \\
\hline \multirow{2}{*}{$\begin{array}{l}\text { Tan and Lopez- } \\
\text { Acevedo (2003) }\end{array}$} & \multirow{2}{*}{$\begin{array}{l}\text { Firm Level Data for } \\
\text { Mexico }(1992,1999)\end{array}$} & \multirow[t]{2}{*}{ log monthly wage } & \multirow{2}{*}{$\begin{array}{l}\text { dummy: firm offered training } \\
\text { in the previous } 12 \text { months }\end{array}$} & \multirow{2}{*}{$\begin{array}{l}\text { average years of schooling of the } \\
\text { workforce, percentage of women, } \\
\text { occupation, ownership, exports, } \\
\text { size, industry and region }\end{array}$} & \multirow{2}{*}{$\begin{array}{l}\text { Training returns } \\
\text { increased from } 5 \% \text { to } \\
7 \% \text { from } 1992 \text { to } \\
1999 .\end{array}$} & Yes \\
\hline & & & & & & $\begin{array}{l}\text { Excluded instruments (selection model): } \\
\text { years in operation, R\&D, computerization, } \\
\text { unionization. }\end{array}$ \\
\hline \multicolumn{7}{|c|}{ Panel D: Papers using industry level data } \\
\hline Name of study & $\begin{array}{l}\text { Country and time } \\
\text { period }\end{array}$ & Dependent variable & Training & Other independent variables & $\begin{array}{l}\text { Effects training on } \\
\text { wages }\end{array}$ & Controls endogeneity training \\
\hline \multirow{2}{*}{$\begin{array}{l}\text { Dearden, Reed } \\
\text { and Reenen (2000) }\end{array}$} & \multirow{2}{*}{$\begin{array}{l}\text { Industry Level Data } \\
\text { for U.K. (1984-1996) }\end{array}$} & \multirow[t]{2}{*}{ log hourly wage } & \multirow{2}{*}{$\begin{array}{l}\text { industry aggregated } \\
\text { incidence for training in the } \\
\text { previous } 4 \text { weeks }\end{array}$} & \multirow{2}{*}{$\begin{array}{l}\text { log capital per worker, log hours } \\
\text { per worker, log of R\&D over sales, } \\
\text { region, time and tenure dummies, } \\
\text { proportion of: men, age groups, } \\
\text { occupation, qualified workers, } \\
\text { small firms. }\end{array}$} & \multirow{2}{*}{$\begin{array}{l}\text { Raising training } \\
\text { incidence by } 5 \% \\
\text { increases wages and } \\
\text { productivity by } 1.6 \% \\
\text { and } 4 \% \text { respectively. }\end{array}$} & Yes \\
\hline & & & & & & Panel data: Within groups estimator \\
\hline
\end{tabular}


Table A2 Variable definitions

\begin{tabular}{|c|c|}
\hline Variable & Definition \\
\hline Firm training & $\begin{array}{l}\text { Dummy variable equal to } 1 \text { if the firm offered formal training to its workers in } \\
\text { the previous year. }\end{array}$ \\
\hline $\begin{array}{l}\text { Micro, small, medium, large, } \\
\text { and very large }\end{array}$ & $\begin{array}{l}\text { Dummy variables equal to } 1 \text { if the total number of employees in the firm is } \\
\text { between } 1 \text { and } 9 \text {, between } 10 \text { and } 49 \text {, between } 50 \text { and } 99 \text {, between } 100 \text { and } \\
249 \text { or greater than 250, respectively. }\end{array}$ \\
\hline Sector & $\begin{array}{l}\text { Two digit industries/services: Food Processing; Textiles; Garments; Wood } \\
\text { Products/Furniture; Pharmaceuticals/Chemicals; Rubber and Plastics, Household } \\
\text { Electrical Appliances; Electronics; Automobiles parts; Machinery and Equipment } \\
\text { / Information Technology; Communication Services; Accounting and Related } \\
\text { Services; Advertising and Marketing; Business Logistics. }\end{array}$ \\
\hline Full foreign-owned & Dummy variable equal to 1 if $100 \%$ of the firm's capital is owned by foreigners. \\
\hline Majority foreign-owned & $\begin{array}{l}\text { Dummy variable equal to } 1 \text { if more than } 50 \% \text { and less than } 100 \% \text { of the firm's } \\
\text { capital is owned by foreigners. }\end{array}$ \\
\hline Minority foreign-owned & $\begin{array}{l}\text { Dummy variable equal to } 1 \text { if more than } 0 \% \text { but less than } 50 \% \text { of the firm's } \\
\text { capital is owned by foreigners. }\end{array}$ \\
\hline Domestic & $\begin{array}{l}\text { Dummy variable equal to } 1 \text { if } 100 \% \text { of the firm's capital is owned by domestic } \\
\text { entities. }\end{array}$ \\
\hline Exporter & Dummy variable equal to 1 if the firm exports are more than $10 \%$ of its sales \\
\hline Share of skilled workers & $\begin{array}{l}\text { Percentage of the firm's workforce that are managers, professionals or skilled } \\
\text { production workers. }\end{array}$ \\
\hline Education labor force & Average years of schooling of the workforce. \\
\hline Age firm & Year of the survey minus the year when the firm started operations. \\
\hline Education of manager & Dummy variable equal to 1 if the manager of the firm owns a degree. \\
\hline New production technology & $\begin{array}{l}\text { Dummy variable equal to } 1 \text { if the firm introduced in the previous two years a } \\
\text { new technology that substantially changed production. }\end{array}$ \\
\hline Training in the firm & $\begin{array}{l}\text { Dummy variable equal to } 1 \text { if the worker received formal training since he } \\
\text { joined the firm. }\end{array}$ \\
\hline Hourly wage & Hourly wage in USD (exchange rate at the time of the survey) \\
\hline Ln wage & Natural logarithm of hourly wage. \\
\hline Woman & Dummy variable equal to 1 if the worker is a woman. \\
\hline Age of worker & Age of the worker \\
\hline Level of education & $\begin{array}{l}\text { Dummy variables equal to } 1 \text { if the highest level of formal education of the worker is } \\
\text { a degree, diploma, upper secondary, lower secondary, primary, respectively. }\end{array}$ \\
\hline Vocational education & Dummy variable equal to 1 if the worker received vocational education. \\
\hline Potential experience & Year of the survey minus the year when the worker found his first permanent job. \\
\hline Tenure with the firm & Year of the survey minus the year when the worker joined the firm. \\
\hline Single & Dummy variable equal to 1 if the worker is single \\
\hline Native & $\begin{array}{l}\text { Dummy variable equal to } 1 \text { if the worker is from the same country were the } \\
\text { firm is registered. }\end{array}$ \\
\hline Studied abroad & Dummy variable equal to 1 if the worker studied abroad. \\
\hline Unionized & Dummy variable equal to 1 if the worker belongs to a trade union. \\
\hline Occupation dummies & $\begin{array}{l}\text { Dummy variables equal to } 1 \text { if the employee works as a manager, professional, } \\
\text { skill production worker, unskilled production worker, non-production worker, } \\
\text { apprentice, respectively. }\end{array}$ \\
\hline Computer & Dummy variable equal to 1 if the worker owns a personal computer at home. \\
\hline Bank account & Dummy variable equal to 1 if the worker has a bank account. \\
\hline Transaction internet & $\begin{array}{l}\text { Dummy variable equal to } 1 \text { if the worker has ever bought or sold a good } \\
\text { through the internet. }\end{array}$ \\
\hline Training other firm & $\begin{array}{l}\text { Dummy variable equal to } 1 \text { if the worker received formal training at the } \\
\text { previous employer. }\end{array}$ \\
\hline
\end{tabular}


Table A3 Summary statistics of the main firm level characteristics

\begin{tabular}{|c|c|c|c|c|}
\hline \multirow[t]{3}{*}{ Variable } & \multicolumn{2}{|c|}{ Malaysia } & \multicolumn{2}{|c|}{ Thailand } \\
\hline & Obs. & Mean & Obs. & Mean \\
\hline & (1) & (2) & (3) & (4) \\
\hline Firm training & 1,145 & 0.51 & 1,385 & 0.76 \\
\hline In-house training & 551 & 0.30 & 1,006 & 0.46 \\
\hline Outside training & 570 & 0.11 & 1,049 & 0.08 \\
\hline Share costs with employees & 553 & 0.05 & 1,056 & 0.03 \\
\hline \multicolumn{5}{|l|}{ Size } \\
\hline Micro & 1,148 & 0.06 & 1,385 & 0.02 \\
\hline Small & 1,148 & 0.43 & 1,385 & 0.28 \\
\hline Medium & 1,148 & 0.20 & 1,385 & 0.19 \\
\hline Large & 1,148 & 0.16 & 1,385 & 0.23 \\
\hline Very large & 1,148 & 0.15 & 1,385 & 0.29 \\
\hline \multicolumn{5}{|l|}{ Ownership } \\
\hline Full foreign-owned & 1,128 & 0.13 & 1,384 & 0.07 \\
\hline Majority foreign-owned & 1,128 & 0.07 & 1,384 & 0.06 \\
\hline Minority foreign-owned & 1,128 & 0.10 & 1,384 & 0.13 \\
\hline Domestic & 1,128 & 0.70 & 1,384 & 0.74 \\
\hline Exporter & 941 & 0.67 & 1,385 & 0.62 \\
\hline Share of skilled workers & 1,149 & 0.49 & 1,385 & 0.24 \\
\hline Education labor force & 1,149 & 10.12 & 1,385 & 9.73 \\
\hline \multicolumn{5}{|l|}{ Sector } \\
\hline Food processing & 1,152 & 0.18 & 1,385 & 0.13 \\
\hline Textiles & 1,152 & 0.03 & 1,385 & 0.13 \\
\hline Garments & 1,152 & 0.09 & 1,385 & 0.12 \\
\hline Automobiles parts & 1,152 & 0.03 & 1,385 & 0.10 \\
\hline Electronics & 1,152 & 0.07 & 1,385 & 0.11 \\
\hline Rubber and plastics & 1,152 & 0.22 & 1,385 & 0.06 \\
\hline Wood products/furniture & 1,152 & 0.00 & 1,385 & 0.17 \\
\hline Machinery and equipment & 1,152 & 0.07 & 1,385 & 0.09 \\
\hline Pharmaceuticals/chemicals & 1,152 & 0.03 & - & - \\
\hline Household electrical appliances & 1,152 & 0.08 & - & - \\
\hline Information technology & 1,152 & 0.03 & - & - \\
\hline Communication services & 1,152 & 0.01 & - & - \\
\hline Accounting and related services & 1,152 & 0.09 & - & - \\
\hline Advertising and marketing & 1,152 & 0.02 & - & - \\
\hline Business logistics & 1,152 & 0.08 & - & - \\
\hline
\end{tabular}

Source: Authors' calculations based on the Enterprise Surveys (World Bank).

Note: Table reports the means of variables listed in the table. Column (1) reports the means for the sample of firms in Malaysia, and column (2) reports the means for the sample of firms in Thailand. 
Table A4 Summary statistics of the main worker level characteristics

\begin{tabular}{|c|c|c|}
\hline Variable & $\begin{array}{c}\text { Malaysia } \\
\text { (1) }\end{array}$ & $\begin{array}{c}\text { Thailand } \\
\text { (2) }\end{array}$ \\
\hline Training in the firm & 0.33 & 0.52 \\
\hline Hourly wages & 0.41 & -0.14 \\
\hline Woman & 0.44 & 0.55 \\
\hline Age of worker & 34.18 & 32.41 \\
\hline \multicolumn{3}{|l|}{ Education } \\
\hline Degree & 0.08 & 0.20 \\
\hline Diploma & 0.12 & 0.11 \\
\hline Upper secondary & 0.36 & 0.20 \\
\hline Lower secondary & 0.27 & 0.18 \\
\hline Primary & 0.15 & 0.30 \\
\hline Illiterate & 0.01 & 0.00 \\
\hline Vocational education & 0.15 & 0.06 \\
\hline Potential experience & 13.61 & 13.85 \\
\hline Tenure with the firm & 7.24 & 5.55 \\
\hline Single & 0.35 & 0.36 \\
\hline Studied abroad & 0.07 & 0.01 \\
\hline Unionized & 0.04 & 0.01 \\
\hline \multicolumn{3}{|l|}{ Occupation } \\
\hline Managers & 0.14 & 0.06 \\
\hline Professionals & 0.08 & 0.08 \\
\hline Skill production & 0.36 & 0.29 \\
\hline Unskilled production & 0.24 & 0.37 \\
\hline Non-production & 0.17 & 0.18 \\
\hline Apprentice & 0.01 & 0.01 \\
\hline Observations & 6,679 & 9,418 \\
\hline
\end{tabular}

Source: Authors' calculations based on the Enterprise Surveys (World Bank).

Note: Table reports the means of variables listed in the table. Column (1) reports the means for the sample of workers in Malaysia, and column (2) reports the means for the sample of workers is Thailand. The wage variables are in USD at current prices at the time of the survey.

Table A5 Average marginal effects for Malaysian firms

\begin{tabular}{lccccccc}
\hline & $\mathbf{( 1 )}$ & $\mathbf{( 2 )}$ & $\mathbf{( 3 )}$ & $\mathbf{( 4 )}$ & $\mathbf{( 5 )}$ & $\mathbf{( 6 )}$ & $\mathbf{( 7 )}$ \\
\hline Small & $0.182^{* *}$ & $0.158^{*}$ & $0.166^{*}$ & $0.151^{*}$ & $0.182^{* *}$ & $0.180^{*}$ & $0.167^{*}$ \\
& {$[0.082]$} & {$[0.088]$} & {$[0.089]$} & {$[0.087]$} & {$[0.092]$} & {$[0.093]$} & {$[0.100]$} \\
Medium & $0.410^{* * *}$ & $0.384^{* * *}$ & $0.404^{* * *}$ & $0.379^{* * *}$ & $0.376^{* * *}$ & $0.376^{* * *}$ & $0.373^{* * *}$ \\
& {$[0.063]$} & {$[0.072]$} & {$[0.072]$} & {$[0.073]$} & {$[0.076]$} & {$[0.077]$} & {$[0.085]$} \\
Large & $0.516^{* * *}$ & $0.487^{* * *}$ & $0.503^{* * *}$ & $0.483^{* * *}$ & $0.462^{* * *}$ & $0.455^{* * *}$ & $0.475^{* * *}$ \\
& {$[0.043]$} & {$[0.057]$} & {$[0.056]$} & {$[0.057]$} & {$[0.062]$} & {$[0.064]$} & {$[0.068]$} \\
Very large & $0.589^{* * *}$ & $0.574^{* * *}$ & $0.588^{* * *}$ & $0.573^{* * *}$ & $0.560^{* * *}$ & $0.549^{* * *}$ & $0.564^{* * *}$ \\
& {$[0.029]$} & {$[0.040]$} & {$[0.039]$} & {$[0.040]$} & {$[0.042]$} & {$[0.046]$} & {$[0.048]$} \\
Age firm & -0.005 & -0.002 & -0.001 & -0.001 & 0.00 & 0.00 & 0.00 \\
& {$[0.004]$} & {$[0.003]$} & {$[0.003]$} & {$[0.003]$} & {$[0.003]$} & {$[0.003]$} & {$[0.003]$} \\
Exporter & & $0.243^{* * *}$ & $0.250^{* * *}$ & $0.244^{* * *}$ & $0.240^{* * *}$ & $0.228^{* * *}$ & $0.240^{* * *}$ \\
& & {$[0.045]$} & {$[0.045]$} & {$[0.045]$} & {$[0.047]$} & {$[0.048]$} & {$[0.049]$}
\end{tabular}


Table A5 Average marginal effects for Malaysian firms (Continued)

\begin{tabular}{|c|c|c|c|c|c|c|c|}
\hline \multirow{2}{*}{\multicolumn{2}{|c|}{ Minority foreign ownership }} & 0.052 & 0.043 & 0.04 & -0.002 & -0.005 & 0.011 \\
\hline & & {$[0.065]$} & {$[0.065]$} & {$[0.066]$} & {$[0.068]$} & {$[0.069]$} & {$[0.071]$} \\
\hline \multirow{2}{*}{\multicolumn{2}{|c|}{ Majority foreign ownership }} & 0.059 & 0.047 & 0.049 & 0.028 & 0.024 & 0.043 \\
\hline & & {$[0.077]$} & {$[0.079]$} & {$[0.078]$} & {$[0.079]$} & {$[0.078]$} & {$[0.079]$} \\
\hline \multirow{2}{*}{\multicolumn{2}{|c|}{ Full foreign ownership }} & $0.131^{* *}$ & $0.121^{* *}$ & $0.121 * *$ & 0.100 & $0.107^{*}$ & $0.113^{*}$ \\
\hline & & {$[0.058]$} & {$[0.059]$} & {$[0.059]$} & {$[0.062]$} & {$[0.064]$} & {$[0.067]$} \\
\hline \multirow{2}{*}{\multicolumn{2}{|c|}{ Share of skilled workers }} & & $0.180^{* *}$ & - & - & - & - \\
\hline & & & {$[0.071]$} & & & & \\
\hline \multirow[t]{2}{*}{ Education labor force } & & & & $0.014^{* * *}$ & $0.011^{* *}$ & $0.010^{* *}$ & $0.008^{*}$ \\
\hline & & & & {$[0.005]$} & {$[0.005]$} & {$[0.005]$} & {$[0.005]$} \\
\hline \multirow[t]{2}{*}{ Education of manager } & & & & & $0.228^{* * *}$ & $0.234^{* * *}$ & $0.234^{* * *}$ \\
\hline & & & & & {$[0.042]$} & {$[0.042]$} & {$[0.043]$} \\
\hline \multirow[t]{2}{*}{ New production technology } & & & & & & $0.136^{* * *}$ & $0.126^{* * *}$ \\
\hline & & & & & & {$[0.045]$} & {$[0.047]$} \\
\hline Industry fixed effects? & Yes & Yes & Yes & Yes & Yes & Yes & No \\
\hline Region fixed effects? & Yes & Yes & Yes & Yes & Yes & Yes & No \\
\hline Industry-region fixed effects? & No & No & No & No & No & No & Yes \\
\hline Observations & 1,132 & 910 & 909 & 909 & 890 & 887 & 869 \\
\hline
\end{tabular}

Source: Authors' calculations based on the Enterprise Surveys (World Bank).

The dependent variable is a dummy variable that assumes the value 1 if the firm offered formal on-the-job training to its employees. The table reports the marginal effects (at mean values) on the firm's propensity to train from probit regressions. Robust standard errors are in brackets. ${ }^{*}$ significant at $10 \%, * *$ significant at $5 \%$, *** significant at $1 \%$. All variables are defined in Table A2. Micro firms (with less than 10 employees) is the omitted size group. Age squared is also included in the regressions (not reported). Industry fixed effects refer to 2 digit industry or service.

Table A6 Average marginal effects for Thai Firms

\begin{tabular}{|c|c|c|c|c|c|c|c|}
\hline & (1) & $(2)$ & (3) & (4) & (5) & (6) & (7) \\
\hline \multirow[t]{2}{*}{ Small } & 0.055 & 0.045 & 0.041 & 0.079 & 0.077 & 0.078 & 0.072 \\
\hline & {$[0.062]$} & [0.062] & {$[0.063]$} & [0.058] & [0.059] & {$[0.057]$} & {$[0.060]$} \\
\hline \multirow[t]{2}{*}{ Medium } & $0.183^{* * *}$ & $0.169^{* * *}$ & $0.166^{* * *}$ & $0.185^{* * *}$ & $0.182^{* * *}$ & $0.177^{* * *}$ & $0.170^{* * *}$ \\
\hline & {$[0.037]$} & [0.039] & [0.039] & {$[0.035]$} & [0.036] & {$[0.035]$} & [0.039] \\
\hline \multirow[t]{2}{*}{ Large } & $0.253^{* * *}$ & $0.235^{* * *}$ & $0.232^{* * *}$ & $0.251^{* * *}$ & $0.248^{* * *}$ & $0.240^{* * *}$ & $0.238^{* * *}$ \\
\hline & [0.034] & [0.035] & {$[0.035]$} & [0.033] & [0.033] & [0.033] & {$[0.035]$} \\
\hline \multirow[t]{2}{*}{ Very large } & $0.326^{* * *}$ & $0.299^{* * *}$ & $0.295^{* * *}$ & $0.318^{* * *}$ & $0.310^{* * *}$ & $0.296^{* * *}$ & $0.279^{* * *}$ \\
\hline & [0.039] & {$[0.040]$} & [0.041] & [0.039] & [0.040] & {$[0.040]$} & {$[0.041]$} \\
\hline \multirow[t]{2}{*}{ Age firm } & 0.004 & 0.004 & 0.004 & 0.004 & 0.005 & 0.005 & 0.006 \\
\hline & {$[0.005]$} & {$[0.004]$} & {$[0.004]$} & {$[0.004]$} & {$[0.004]$} & {$[0.004]$} & {$[0.005]$} \\
\hline \multirow[t]{2}{*}{ Exporter } & & $0.059^{* *}$ & $0.060^{* *}$ & $0.049^{*}$ & 0.045 & 0.042 & $0.048^{*}$ \\
\hline & & [0.028] & {$[0.028]$} & [0.027] & {$[0.027]$} & {$[0.027]$} & {$[0.027]$} \\
\hline \multirow[t]{2}{*}{ Minority foreign ownership } & & 0.004 & 0.004 & -0.006 & -0.008 & -0.009 & -0.002 \\
\hline & & {$[0.036]$} & {$[0.036]$} & {$[0.037]$} & {$[0.037]$} & {$[0.038]$} & {$[0.038]$} \\
\hline \multirow[t]{2}{*}{ Majority foreign ownership } & & $0.123^{* * *}$ & $0.123^{* * *}$ & $0.105^{* *}$ & $0.104^{* *}$ & $0.099^{* *}$ & $0.117^{* * *}$ \\
\hline & & {$[0.040]$} & {$[0.040]$} & {$[0.045]$} & {$[0.046]$} & {$[0.048]$} & {$[0.040]$} \\
\hline \multirow[t]{2}{*}{ Full foreign ownership } & & -0.031 & -0.03 & -0.062 & -0.069 & -0.073 & -0.042 \\
\hline & & {$[0.067]$} & {$[0.067]$} & {$[0.069]$} & {$[0.070]$} & {$[0.072]$} & {$[0.064]$} \\
\hline \multirow[t]{2}{*}{ Share of skilled workers } & & & -0.035 & - & - & - & - \\
\hline & & & {$[0.049]$} & & & & \\
\hline
\end{tabular}


Table A6 Average marginal effects for Thai Firms (Continued)

\begin{tabular}{|c|c|c|c|c|c|c|c|}
\hline \multirow[t]{2}{*}{ Education labor force } & & & & $0.026^{* * *}$ & $0.024^{* * *}$ & $0.022^{* * *}$ & $0.021^{* * *}$ \\
\hline & & & & {$[0.005]$} & {$[0.005]$} & {$[0.005]$} & {$[0.005]$} \\
\hline \multirow[t]{2}{*}{ Education of manager } & & & & & $0.059^{* *}$ & $0.051^{* *}$ & $0.071^{* * *}$ \\
\hline & & & & & {$[0.026]$} & {$[0.026]$} & {$[0.026]$} \\
\hline \multirow[t]{2}{*}{ New production technology } & & & & & & $0.078^{* * *}$ & $0.085^{* * *}$ \\
\hline & & & & & & {$[0.023]$} & {$[0.023]$} \\
\hline Industry fixed effects? & Yes & Yes & Yes & Yes & Yes & Yes & No \\
\hline Region fixed effects? & Yes & Yes & Yes & Yes & Yes & Yes & No \\
\hline Industry-region fixed effects? & No & No & No & No & No & No & Yes \\
\hline Observations & 1,278 & 1,277 & 1,277 & 1,277 & 1,277 & 1,277 & 1,348 \\
\hline
\end{tabular}

Source: Authors' calculations based on the Enterprise Surveys (World Bank).

The dependent variable is a dummy variable that assumes the value 1 if the firm offered formal on-the-job training to its employees. The table reports the marginal effects (at mean values) on the firm's propensity to train from probit regressions. Robust standard errors are in brackets. ${ }^{*}$ significant at $10 \%$, ${ }^{* *}$ significant at $5 \%,{ }^{* * *}$ significant at $1 \%$. All variables are defined in Table A2. Micro firms (with less than 10 employees) is the omitted size group. Age squared is also included in the regressions (not reported). Industry fixed effects refer to 2 digit industry or service.

Table A7 Average marginal effects for Malaysian workers

\begin{tabular}{|c|c|c|c|c|c|}
\hline & (1) & (2) & (3) & (4) & (5) \\
\hline \multirow[t]{2}{*}{ Degree } & $0.713^{* * *}$ & $0.653^{* * *}$ & $0.649^{* * *}$ & $0.606^{* * *}$ & $0.523^{* * *}$ \\
\hline & {$[0.181]$} & {$[0.182]$} & {$[0.184]$} & {$[0.184]$} & {$[0.186]$} \\
\hline \multirow[t]{2}{*}{ Diploma } & $0.783^{* * *}$ & $0.730^{* * *}$ & $0.726^{* * *}$ & $0.711^{* * *}$ & $0.608^{* * *}$ \\
\hline & {$[0.176]$} & {$[0.177]$} & {$[0.179]$} & {$[0.179]$} & {$[0.180]$} \\
\hline \multirow[t]{2}{*}{ Upper secondary } & $0.552^{* * *}$ & $0.521^{* * *}$ & $0.516^{* * *}$ & $0.514^{* * *}$ & $0.458^{* * *}$ \\
\hline & {$[0.170]$} & {$[0.170]$} & {$[0.171]$} & {$[0.171]$} & {$[0.172]$} \\
\hline \multirow[t]{2}{*}{ Lower secondary } & $0.308^{*}$ & $0.287^{*}$ & $0.283^{*}$ & 0.282 & 0.266 \\
\hline & {$[0.170]$} & {$[0.170]$} & {$[0.172]$} & {$[0.171]$} & {$[0.172]$} \\
\hline \multirow[t]{2}{*}{ Primary } & 0.026 & 0.018 & 0.015 & 0.015 & 0.036 \\
\hline & {$[0.175]$} & {$[0.175]$} & {$[0.175]$} & {$[0.175]$} & {$[0.176]$} \\
\hline \multirow[t]{2}{*}{ Vocational education } & $0.170^{* * *}$ & $0.162^{* * *}$ & $0.162^{* * *}$ & $0.162^{* * *}$ & $0.101^{* *}$ \\
\hline & {$[0.048]$} & {$[0.048]$} & {$[0.049]$} & {$[0.049]$} & {$[0.049]$} \\
\hline \multirow[t]{2}{*}{ Woman } & $-0.095^{* * *}$ & $-0.098^{* * *}$ & $-0.099^{* * *}$ & $-0.095^{* * *}$ & -0.071 \\
\hline & {$[0.037]$} & {$[0.037]$} & {$[0.037]$} & {$[0.037]$} & {$[0.038]$} \\
\hline \multirow[t]{2}{*}{ Age of worker } & 0.011 & 0.011 & 0.011 & 0.012 & 0.020 \\
\hline & {$[0.019]$} & {$[0.019]$} & {$[0.019]$} & {$[0.019]$} & {$[0.019]$} \\
\hline \multirow[t]{2}{*}{ Tenure with the firm } & $0.047^{* * *}$ & $0.046^{* * *}$ & $0.046^{* * *}$ & $0.046^{* * *}$ & $0.069^{* * *}$ \\
\hline & {$[0.009]$} & {$[0.009]$} & {$[0.009]$} & {$[0.009]$} & {$[0.001]$} \\
\hline \multirow[t]{2}{*}{ Potential experience } & -0.011 & -0.011 & -0.012 & -0.012 & $-0.032^{* * *}$ \\
\hline & {$[0.009]$} & {$[0.009]$} & {$[0.009]$} & {$[0.009]$} & {$[0.009]$} \\
\hline \multirow[t]{2}{*}{ Single } & $-0.180^{* * *}$ & $-0.182^{* * *}$ & $-0.182^{* * *}$ & $-0.181^{* * *}$ & $-0.146^{* * *}$ \\
\hline & {$[0.044]$} & {$[0.044]$} & {$[0.044]$} & {$[0.045]$} & {$[0.045]$} \\
\hline \multirow[t]{2}{*}{ Manager } & $0.142^{* *}$ & $0.128^{* *}$ & $0.129^{* *}$ & $0.117^{* *}$ & 0.060 \\
\hline & {$[0.064]$} & {$[0.064]$} & {$[0.064]$} & {$[0.064]$} & {$[0.066]$} \\
\hline \multirow[t]{2}{*}{ Professional } & $0.165^{* *}$ & 0.157 & 0.157 & 0.153 & 0.118 \\
\hline & {$[0.076]$} & {$[0.076]$} & {$[0.076]$} & {$[0.076]$} & {$[0.078]$} \\
\hline
\end{tabular}


Table A7 Average marginal effects for Malaysian workers (Continued)

\begin{tabular}{|c|c|c|c|c|c|}
\hline \multirow[t]{2}{*}{ Skill Production } & -0.031 & -0.021 & -0.021 & -0.018 & -0.017 \\
\hline & {$[0.053]$} & {$[0.053]$} & {$[0.053]$} & {$[0.053]$} & {$[0.054]$} \\
\hline \multirow[t]{2}{*}{ Unskilled Production } & $-0.298^{* * *}$ & $-0.280^{* * *}$ & $-0.279^{* * *}$ & $-0.276^{* * *}$ & $-0.269^{* * *}$ \\
\hline & {$[0.061]$} & {$[0.061]$} & {$[0.061]$} & {$[0.061]$} & {$[0.062]$} \\
\hline \multirow[t]{2}{*}{ Apprentice } & 0.433 & 0.453 & 0.455 & 0.462 & $0.506^{* *}$ \\
\hline & {$[0.203]$} & {$[0.203]$} & {$[0.203]$} & {$[0.203]$} & {$[0.204]$} \\
\hline \multirow[t]{2}{*}{ Unionized } & $0.522^{* * *}$ & $0.519^{* * *}$ & $0.519 * * *$ & $0.514^{* * *}$ & $0.531^{* * *}$ \\
\hline & {$[0.087]$} & {$[0.087]$} & {$[0.088]$} & {$[0.088]$} & {$[0.088]$} \\
\hline \multirow[t]{2}{*}{ Computer } & & $0.119^{* * *}$ & $0.119^{* * *}$ & $0.112^{* * *}$ & $0.108^{* * *}$ \\
\hline & & {$[0.038]$} & {$[0.039]$} & {$[0.039]$} & {$[0.040]$} \\
\hline \multirow[t]{2}{*}{ Bank Account } & & & 0.019 & 0.016 & -0.040 \\
\hline & & & {$[0.095]$} & {$[0.095]$} & {$[0.095]$} \\
\hline \multirow[t]{2}{*}{ Transaction Internet } & & & & $0.334^{* * *}$ & $0.277^{* * *}$ \\
\hline & & & & {$[0.094]$} & {$[0.095]$} \\
\hline \multirow[t]{2}{*}{ Training at the Previous Firm } & & & & & $0.793^{* * *}$ \\
\hline & & & & & {$[0.048]$} \\
\hline Observations & 6,679 & 6,679 & 6,679 & 6,679 & 6,679 \\
\hline
\end{tabular}

Source: Authors' calculations based on the Enterprise Surveys (World Bank).

The dependent variable is a dummy variable that assumes the value 1 if the received formal on-the-job training since he joined the firm. The table reports the marginal effects (at mean values) on the worker's propensity to be trained from probit regressions. Robust standard errors are in brackets. ${ }^{*}$ significant at $10 \%$, ** significant at $5 \%,{ }^{* * *}$ significant at $1 \%$. All variables are defined in Table A2. Firm Base Specification is the same as in column (7) of Table A5. Illiterate and Non-production workers are the omitted education and occupation groups. Age squared, Tenure squared and Experience squared are also included in the regressions (not reported).

Table A8 Average marginal effects for Thai workers

\begin{tabular}{lccccc}
\hline & $\mathbf{( 1 )}$ & $\mathbf{( 2 )}$ & $\mathbf{( 3 )}$ & $\mathbf{( 4 )}$ & $\mathbf{( 5 )}$ \\
\hline Degree & $0.797^{* * *}$ & $0.717^{* * *}$ & $0.593^{* * *}$ & $0.586^{* * *}$ & $0.426^{* *}$ \\
& {$[0.210]$} & {$[0.211]$} & {$[0.216]$} & {$[0.216]$} & {$[0.215]$} \\
Diploma & $0.662^{* * *}$ & $0.617^{* * *}$ & $0.494^{* * *}$ & $0.493^{* * *}$ & 0.353 \\
& {$[0.210]$} & {$[0.211]$} & {$[0.215]$} & {$[0.216]$} & {$[0.215]$} \\
Upper secondary & $0.484^{* * *}$ & $0.463^{* * *}$ & $0.347^{*}$ & 0.345 & 0.226 \\
Lower secondary & {$[0.207]$} & {$[0.208]$} & {$[0.212]$} & {$[0.212]$} & {$[0.212]$} \\
& 0.340 & 0.334 & 0.239 & 0.237 & 0.114 \\
Primary & {$[0.207]$} & {$[0.208]$} & {$[0.212]$} & {$[0.212]$} & {$[0.211]$} \\
Vocational education & 0.116 & 0.119 & 0.051 & 0.049 & -0.034 \\
Woman & {$[0.205]$} & {$[0.206]$} & {$[0.210]$} & {$[0.210]$} & {$[0.209]$} \\
& 0.075 & 0.067 & 0.058 & 0.050 & -0.015 \\
Age of worker & {$[0.058]$} & {$[0.058]$} & {$[0.058]$} & {$[0.058]$} & {$[0.059]$} \\
Tenure with the firm & $-0.048^{*}$ & $-0.046^{*}$ & $-0.066^{* *}$ & $-0.066^{* *}$ & $-0.072^{*}$ \\
Potential experience & {$[0.029]$} & {$[0.029]$} & {$[0.029]$} & {$[0.029]$} & {$[0.030]$} \\
& 0.025 & $0.026^{*}$ & 0.023 & 0.023 & 0.020 \\
& {$[0.015]$} & {$[0.015]$} & {$[0.016]$} & {$[0.016]$} & {$[0.016]$} \\
& $0.085^{* * *}$ & $0.085^{* * *}$ & $0.083^{* * *}$ & $0.082^{* * *}$ & $0.100^{* * *}$ \\
& {$[0.007]$} & {$[0.008]$} & {$[0.008]$} & {$[0.008]$} & {$[0.008]$} \\
& 0.005 & 0.004 & 0.003 & 0.003 & -0.003 \\
& {$[0.007]$} & {$[0.007]$} & {$[0.007]$} & {$[0.007]$} & {$[0.008]$}
\end{tabular}


Table A8 Average marginal effects for Thai workers (Continued)

\begin{tabular}{|c|c|c|c|c|c|}
\hline \multirow[t]{2}{*}{ Single } & 0.001 & 0.003 & 0.012 & 0.012 & 0.022 \\
\hline & {$[0.032]$} & {$[0.032]$} & {$[0.033]$} & {$[0.033]$} & {$[0.033]$} \\
\hline \multirow[t]{2}{*}{ Manager } & -0.002 & -0.042 & -0.047 & -0.065 & -0.087 \\
\hline & {$[0.068]$} & {$[0.068]$} & {$[0.068]$} & {$[0.068]$} & {$[0.070]$} \\
\hline \multirow[t]{2}{*}{ Professional } & -0.021 & -0.041 & -0.047 & -0.051 & -0.055 \\
\hline & {$[0.059]$} & {$[0.059]$} & {$[0.059]$} & {$[0.059]$} & {$[0.059]$} \\
\hline \multirow[t]{2}{*}{ Skill production } & $0.176^{* * *}$ & $0.183^{* * *}$ & $0.185^{* * *}$ & $0.185^{* * *}$ & $0.181^{* * *}$ \\
\hline & {$[0.045]$} & {$[0.045]$} & {$[0.045]$} & {$[0.045]$} & {$[0.046]$} \\
\hline \multirow[t]{2}{*}{ Unskilled production } & $0.218^{* * *}$ & $0.229^{* * *}$ & $0.239^{* * *}$ & $0.237^{* * *}$ & $0.225^{* * *}$ \\
\hline & {$[0.046]$} & {$[0.046]$} & {$[0.046]$} & {$[0.046]$} & {$[0.047]$} \\
\hline \multirow[t]{2}{*}{ Apprentice } & -0.291 & -0.281 & -0.272 & -0.272 & -0.234 \\
\hline & {$[0.173]$} & {$[0.173]$} & {$[0.173]$} & {$[0.173]$} & {$[0.174]$} \\
\hline \multirow[t]{2}{*}{ Unionized } & $0.635^{* * *}$ & $0.636^{* * *}$ & $0.635^{* * *}$ & $0.637^{* * *}$ & $0.628^{* * *}$ \\
\hline & {$[0.143]$} & {$[0.143]$} & {$[0.143]$} & {$[0.143]$} & {$[0.144]$} \\
\hline \multirow[t]{2}{*}{ Computer } & & $0.177^{* * *}$ & $0.163^{* * *}$ & $0.158^{* * *}$ & $0.143^{* * *}$ \\
\hline & & [0.039] & [0.039] & {$[0.039]$} & {$[0.040]$} \\
\hline \multirow[t]{2}{*}{ Bank account } & & & $0.465^{* * *}$ & $0.465^{* * *}$ & $0.475^{* * *}$ \\
\hline & & & {$[0.052]$} & {$[0.052]$} & {$[0.052]$} \\
\hline \multirow[t]{2}{*}{ Transaction internet } & & & & $0.293^{* *}$ & 0.193 \\
\hline & & & & {$[0.140]$} & {$[0.141]$} \\
\hline \multirow[t]{2}{*}{ Training at the previous firm } & & & & & $0.607^{* * *}$ \\
\hline & & & & & {$[0.014]$} \\
\hline Observations & 9,418 & 9,418 & 9,418 & 9,418 & 9,418 \\
\hline
\end{tabular}

Source: Authors' calculations based on the Enterprise Surveys (World Bank).

The dependent variable is a dummy variable that assumes the value 1 if the received formal on-the-job training since he joined the firm. The table reports the marginal effects (at mean values) on the worker's propensity to be trained from probit regressions. Robust standard errors are in brackets. * significant at $10 \%$, ${ }^{* *}$ significant at $5 \%,{ }^{* * *}$ significant at $1 \%$. All variables are defined in Table A2. Firm Base Specification is the same as in column (7) of Table A6. Illiterate and Nonproduction workers are the omitted education and occupation groups. Age squared, Tenure squared and Experience squared are also included in the regressions (not reported).

Table A9 Wage returns to job training in Malaysia

\begin{tabular}{lccc}
\hline & $\mathbf{( 1 )}$ & $\mathbf{( 2 )}$ & $\mathbf{( 3 )}$ \\
\hline Training in the firm & $0.431^{* * *}$ & $0.081^{* * *}$ & $0.043^{* * *}$ \\
& {$[0.037]$} & {$[0.026]$} & {$[0.027]$} \\
Degree & & $0.739^{* * *}$ & $0.637^{* * *}$ \\
& & {$[0.077]$} & {$[0.071]$} \\
Diploma & $0.453^{* * *}$ & $0.383^{* * *}$ \\
& & {$[0.073]$} & {$[0.067]$} \\
Upper secondary & $0.209^{* * *}$ & $0.187^{* * *}$ \\
& & {$[0.067]$} & {$[0.061]$} \\
Lower secondary & $0.181^{* * *}$ & $0.152^{* * *}$ \\
Primary & {$[0.066]$} & {$[0.060]$} \\
Vocational education & 0.010 & 0.007 \\
& & {$[0.063]$} & {$[0.058]$} \\
& & $0.114^{* * *}$ & $0.075^{* * *}$ \\
& & {$[0.023]$} & {$[0.020]$}
\end{tabular}


Table A9 Wage returns to job training in Malaysia (Continued)

\begin{tabular}{|c|c|c|c|}
\hline \multirow{2}{*}{ Woman } & & $-0.203^{* * *}$ & $-0.187^{* * *}$ \\
\hline & & {$[0.019]$} & {$[0.018]$} \\
\hline \multirow[t]{2}{*}{ Age of worker } & & $0.031^{* * *}$ & $0.029^{* * *}$ \\
\hline & & {$[0.008]$} & {$[0.008]$} \\
\hline \multirow[t]{2}{*}{ Tenure with the firm } & & $0.027^{* * *}$ & $0.027^{* * *}$ \\
\hline & & {$[0.005]$} & {$[0.004]$} \\
\hline \multirow[t]{2}{*}{ Potential experience } & & $0.017^{* * *}$ & $0.016^{* * *}$ \\
\hline & & {$[0.004]$} & {$[0.004]$} \\
\hline \multirow[t]{2}{*}{ Single } & & $-0.072^{* * *}$ & $-0.067^{* * *}$ \\
\hline & & {$[0.020]$} & {$[0.019]$} \\
\hline \multirow[t]{2}{*}{ Manager } & & $0.384^{* * *}$ & $0.381^{* * *}$ \\
\hline & & {$[0.036]$} & {$[0.032]$} \\
\hline \multirow[t]{2}{*}{ Professional } & & $0.302^{* * *}$ & $0.264^{* * *}$ \\
\hline & & {$[0.041]$} & {$[0.037]$} \\
\hline \multirow[t]{2}{*}{ Skill production } & & $-0.079^{* * *}$ & $-0.091^{* * *}$ \\
\hline & & {$[0.033]$} & {$[0.028]$} \\
\hline \multirow[t]{2}{*}{ Unskilled production } & & $-0.350^{* * *}$ & $-0.366^{* * *}$ \\
\hline & & {$[0.035]$} & {$[0.031]$} \\
\hline \multirow[t]{2}{*}{ Apprentice } & & $-0.276^{* * *}$ & $-0.300^{* * *}$ \\
\hline & & {$[0.068]$} & {$[0.072]$} \\
\hline \multirow[t]{2}{*}{ Unionized } & & $-0.064^{* *}$ & $-0.085^{* *}$ \\
\hline & & {$[0.055]$} & {$[0.051]$} \\
\hline \multirow[t]{2}{*}{ Computer } & & $0.173^{* * *}$ & $0.153^{* * *}$ \\
\hline & & {$[0.020]$} & {$[0.018]$} \\
\hline \multirow[t]{2}{*}{ Bank account } & & $0.179^{* * *}$ & $0.130^{* * *}$ \\
\hline & & {$[0.041]$} & {$[0.041]$} \\
\hline \multirow[t]{2}{*}{ Transaction internet } & & $0.175^{* * *}$ & $0.094^{* *}$ \\
\hline & & {$[0.062]$} & {$[0.048]$} \\
\hline \multirow{2}{*}{\multicolumn{2}{|c|}{ Training at the previous firm }} & $0.091^{* * *}$ & $0.068^{* * *}$ \\
\hline & & {$[0.026]$} & {$[0.026]$} \\
\hline Firm base specification & No & No & Yes \\
\hline Observations & 6,679 & 6,679 & 6,679 \\
\hline
\end{tabular}

Source: Authors' calculations based on the Enterprise Surveys (World Bank).

Note: The table reports the estimates for equation 5 in the text. Robust standard errors, clustered at firm level, are in brackets. * significant at $10 \%,{ }^{* *}$ significant at $5 \%$, *** significant at $1 \%$. The dependent variable is the log hourly wage. Column (1) only controls for job training, column (2) adds baseline worker characteristics as in column (8) of Table A7 and A8. Column (3) adds firm baseline characteristics as in column (7) of Tables A5 and A6. Illiterate and Non-production workers are the omitted education and occupation groups. Age squared, Tenure squared and Experience squared are also included in the regressions (not reported). 
Table A10 Wage returns to job training in Thailand

\begin{tabular}{|c|c|c|c|}
\hline & (1) & $(2)$ & (3) \\
\hline \multirow[t]{2}{*}{ Training in the firm } & $0.284^{* * *}$ & $0.062^{* * *}$ & $0.042^{* * *}$ \\
\hline & {$[0.022]$} & {$[0.014]$} & {$[0.015]$} \\
\hline \multirow[t]{2}{*}{ Degree } & & $0.752^{* * *}$ & $0.743^{* * *}$ \\
\hline & & {$[0.065]$} & {$[0.069]$} \\
\hline \multirow[t]{2}{*}{ Diploma } & & $0.477^{* * *}$ & $0.454^{* * *}$ \\
\hline & & {$[0.063]$} & {$[0.068]$} \\
\hline \multirow[t]{2}{*}{ Upper secondary } & & $0.295^{* * *}$ & $0.283^{* * *}$ \\
\hline & & {$[0.061]$} & {$[0.066]$} \\
\hline \multirow[t]{2}{*}{ Lower secondary } & & $0.176^{* * *}$ & $0.178^{* *}$ \\
\hline & & {$[0.060]$} & {$[0.065]$} \\
\hline \multirow[t]{2}{*}{ Primary } & & 0.056 & 0.087 \\
\hline & & {$[0.059]$} & {$[0.064]$} \\
\hline \multirow[t]{2}{*}{ Vocational education } & & -0.012 & -0.030 \\
\hline & & {$[0.024]$} & {$[0.024]$} \\
\hline \multirow[t]{2}{*}{ Woman } & & $-0.168^{* * *}$ & $-0.163^{* * *}$ \\
\hline & & {$[0.013]$} & {$[0.012]$} \\
\hline \multirow[t]{2}{*}{ Age of worker } & & $0.026^{* * *}$ & $0.022^{* * *}$ \\
\hline & & {$[0.007]$} & {$[0.006]$} \\
\hline \multirow[t]{2}{*}{ Tenure with the firm } & & $0.035^{* * *}$ & $0.032^{* * *}$ \\
\hline & & {$[0.004]$} & {$[0.004]$} \\
\hline \multirow[t]{2}{*}{ Potential experience } & & $0.009^{* * *}$ & $0.008^{* * *}$ \\
\hline & & {$[0.001]$} & {$[0.001]$} \\
\hline \multirow[t]{2}{*}{ Single } & & $-0.031^{* *}$ & $-0.046^{* * *}$ \\
\hline & & {$[0.013]$} & {$[0.012]$} \\
\hline \multirow[t]{2}{*}{ Manager } & & $0.568^{* * *}$ & $0.585^{* * *}$ \\
\hline & & {$[0.041]$} & {$[0.041]$} \\
\hline \multirow[t]{2}{*}{ Professional } & & $0.198^{* * *}$ & $0.190^{* * *}$ \\
\hline & & {$[0.028]$} & {$[0.027]$} \\
\hline \multirow[t]{2}{*}{ Skill production } & & -0.025 & -0.020 \\
\hline & & {$[0.018]$} & {$[0.019]$} \\
\hline \multirow[t]{2}{*}{ Unskilled production } & & $-0.180^{* * *}$ & $-0.179 * * *$ \\
\hline & & {$[0.018]$} & {$[0.019]$} \\
\hline \multirow[t]{2}{*}{ Apprentice } & & -0.081 & $-0.186^{* *}$ \\
\hline & & {$[0.124]$} & {$[0.125]$} \\
\hline \multirow[t]{2}{*}{ Unionized } & & 0.028 & -0.079 \\
\hline & & {$[0.056]$} & {$[0.053]$} \\
\hline \multirow[t]{2}{*}{ Computer } & & $0.214^{* * *}$ & $0.189 * * *$ \\
\hline & & {$[0.018]$} & {$[0.017]$} \\
\hline \multirow[t]{2}{*}{ Bank account } & & $0.111^{* * *}$ & $0.087^{* * *}$ \\
\hline & & {$[0.019]$} & {$[0.019]$} \\
\hline
\end{tabular}


Table A10 Wage returns to job training in Thailand (Continued)

\begin{tabular}{|c|c|c|c|}
\hline \multirow[t]{2}{*}{ Transaction internet } & & $0.312^{* * *}$ & $0.281^{* * *}$ \\
\hline & & {$[0.064]$} & {$[0.060]$} \\
\hline \multirow[t]{2}{*}{ Training at the previous firm } & & 0.011 & $0.027^{* *}$ \\
\hline & & {$[0.016]$} & {$[0.015]$} \\
\hline Firm base specification & No & No & Yes \\
\hline Observations & 9418 & 9418 & 9418 \\
\hline
\end{tabular}

Source: Authors' calculations based on the Enterprise Surveys (World Bank).

Note: The table reports the estimates for equation 5 in the text. Robust standard errors, clustered at firm level, are in brackets. * significant at $10 \%,{ }^{* *}$ significant at $5 \%,{ }^{* *}$ significant at $1 \%$. The dependent variable is the log hourly wage. Column (1) only controls for job training, column (2) adds baseline worker characteristics as in column (8) of Table A7 and A8. Column (3) adds firm baseline characteristics as in column (7) of Tables A5 and A6. Illiterate and Non-production workers are the omitted education and occupation groups. Age squared, Tenure squared and Experience squared are also included in the regressions (not reported)

Table A11 Balancing tests

\begin{tabular}{|c|c|c|c|c|c|c|}
\hline & \multicolumn{2}{|c|}{ Malaysia } & \multirow[b]{2}{*}{$\begin{array}{c}\text { T-test } \\
(3)\end{array}$} & \multicolumn{2}{|c|}{ Thailand } & \multirow[b]{2}{*}{$\begin{array}{c}\text { T-test } \\
(6)\end{array}$} \\
\hline & $\begin{array}{c}\text { Treated means } \\
\text { (1) }\end{array}$ & $\begin{array}{c}\text { Matched means } \\
\text { (2) }\end{array}$ & & $\begin{array}{c}\text { Treated means } \\
\text { (4) }\end{array}$ & $\begin{array}{c}\text { Matched means } \\
\text { (5) }\end{array}$ & \\
\hline Training other firm & 0.323 & 0.332 & -0.62 & 0.322 & 0.310 & 1.27 \\
\hline Woman & 0.424 & 0.436 & -0.17 & 0.558 & 0.554 & 0.41 \\
\hline Age of worker & 33.396 & 32.930 & 1.88 & 32.610 & 32.605 & 0.04 \\
\hline \multicolumn{7}{|l|}{ Education } \\
\hline Degree & 0.137 & 0.136 & 0.02 & 0.257 & 0.253 & 0.47 \\
\hline Diploma & 0.193 & 0.200 & -0.61 & 0.134 & 0.139 & -0.69 \\
\hline Upper secondary & 0.416 & 0.408 & 0.54 & 0.216 & 0.220 & -0.50 \\
\hline Lower secondary & 0.197 & 0.193 & 0.34 & 0.170 & 0.163 & 0.84 \\
\hline Primary & 0.052 & 0.055 & -0.48 & 0.220 & 0.221 & -0.15 \\
\hline Illiterate & 0.001 & 0.003 & -0.77 & 0.003 & 0.003 & -0.18 \\
\hline Vocational education & 0.237 & 0.259 & -1.72 & 0.070 & 0.072 & -0.40 \\
\hline Potential experience & 12.654 & 12.140 & 2.10 & 14.021 & 13.802 & 0.80 \\
\hline Tenure with the firm & 7.566 & 6.996 & 3.14 & 6.107 & 6.055 & 0.52 \\
\hline Single & 0.317 & 0.342 & -1.77 & 0.366 & 0.368 & -0.21 \\
\hline Studied abroad & 0.079 & 0.073 & 0.71 & 0.011 & 0.012 & -0.70 \\
\hline Unionized & 0.075 & 0.070 & 0.63 & 0.021 & 0.018 & 1.47 \\
\hline \multicolumn{7}{|l|}{ Occupation } \\
\hline Managers & 0.208 & 0.204 & 0.31 & 0.075 & 0.078 & -0.52 \\
\hline Professionals & 0.134 & 0.146 & -1.19 & 0.098 & 0.094 & 0.70 \\
\hline Skill production & 0.344 & 0.339 & 0.30 & 0.300 & 0.295 & 0.58 \\
\hline Unskilled production & 0.119 & 0.122 & -0.31 & 0.332 & 0.320 & 1.17 \\
\hline Non-production & 0.186 & 0.177 & 0.76 & 0.190 & 0.207 & -2.12 \\
\hline Apprentice & 0.010 & 0.011 & -0.44 & 0.004 & 0.005 & -0.60 \\
\hline
\end{tabular}

Source: Authors' calculations based on the Enterprise Surveys (World Bank).

Note: The table reports balancing tests between the sample means of the variables listed. We contrast the means of the subsample of treated and untreated individuals. The t-test reported in column (3) and (6) for Malaysia and Thailand, respectively, verifies if the difference between the means of the variables reported is, for each country, statistically different from zero across the two samples. Treated individuals are those that participated in training, and untreated individuals are those reporting not having participated in training. 


\section{A2. Least squares returns to on-the-job training}

Following Mincer, 1974, we assume that $(\log )$ wages are a linear function of several human capital and other worker characteristics, and of firm characteristics:

$$
\ln w_{i j}=\beta \operatorname{Train}_{i j}+\lambda X_{i j}+\phi Z_{j}+\varepsilon_{i j}
$$

where $w_{i j}$ is the worker's hourly wage (local currency) for worker $i$ in firm $j$, $\operatorname{Train}_{i j}$ is a dummy variable equal to one if the worker received formal training since he joined firm $j, X_{i j}$ is a vector of the worker's characteristics, $Z_{j}$ is a vector of firm level characteristics and $\varepsilon_{i j}$ captures the unobserved characteristics of worker $i$ in firm $j$ correlated with hourly wages. Our main parameter of interest is the coefficient $\beta$. $\beta$ captures the percentage point difference in the hourly wage for workers who have received formal on-the-job training in firm $j$. We estimate equation 1 with least squares and cluster the standard errors at the firm level.

The least squares estimates for $\beta$ are consistent if $\operatorname{Train}_{i j}$ is uncorrelated with the error term $\varepsilon_{i j}$. However, this assumption may not hold. On the one hand, there is likely self selection into on-the-job training. We have shown that workers with certain observable characteristics (and most likely also unobservable) are more likely to have taken on-the-job training programs than others. Therefore, it is possible that the higher earnings for those who are trained are caused not by training itself but because those taking up training could have a greater earning capacity and ability than the nontrainees. In this case, the least squares estimates of $\beta$ will probably be upward biased due to a possible "ability bias". On the other hand, if the variable on-the-job training is measured with error, the least squares estimates could be downward biased. Therefore the overall sign of the least square bias is unclear.

We minimize the first problem by accounting in the reduced form for several observable individual and firms characteristics simultaneously correlated with training and also with hourly wages. In particular, in $X_{i j}$ we include detailed information on schooling, gender, age, tenure in the firm, potential experience, marital status, occupation, ethnicity and age. In $Z_{j}$ we include information on firm size, foreign ownership, exports, average schooling of the workforce, managerial ability, degree of technological innovation, industry and geographical location of the firm.

Tables A9 and A10 report the least square estimates for $\beta$ when exploring different specifications and after clustering the standard errors at the firm level. Column (1) controls only for training incidence since joining the firm, column (2) adds the baseline worker characteristics (as in column (6) of Tables A7 and A8) ${ }^{21}$, column (3) adds the baseline firm characteristics (reported in column (7) of Tables A5 and A6) ${ }^{22}$ to the specification in column (3).

The OLS estimates strongly suggest that there are positive returns to the investment in on-the-job training in both countries. As expected, the magnitude of the returns decreases as we introduce additional firm and worker controls. In Table A9, the wage returns of on-the-job training for Malaysia start at $43.1 \%$ but fall to $8.1 \%$ when we control for worker characteristics and to $4.3 \%$ once we control for firm characteristics. Table A10 reports similar findings for Thailand. Returns start at $28.4 \%$ falling to $6.2 \%$ when we include workers characteristics and to $4.2 \%$ when we include firm characteristics $^{23}$. 


\section{Competing interests}

The "Journal of Labor \& Development" is committed to the IZA Guiding Principles of Research Integrity. The authors declare that they have observed these principles.

\section{Authors' contributions}

Rita Almeida and Marta Faria carried out the treatment and econometric analysis of the data, and they both drafted the manuscript. The authors read and approved the final manuscript.

\section{Acknowledgement}

We thank the anonymous comments of a referee and the editor as well as the financial support provided by the Development Economics Research Support Grant (World Bank). Address: Travessa Palma, 1649-023 Lisboa. E-mail: martalincefaria@gmail.com, ralmeida@worldbank.org. The findings expressed in this paper are those of the author and do not necessarily represent the views of the World Bank. We also thank Leonor Modesto, Miguel Gouveia, Pedro Raposo and participants of the IZA conference, Cape Town $3^{\text {rd }}$ and $4^{\text {th }}$ of May 2010. Responsible editor: Hartmut Lehmann.

\section{Author details}

${ }^{1}$ The World Bank and IZA, Lisbon, Portugal. ${ }^{2}$ Católica Lisbon, SBE, Lisbon, Portugal.

Received: 31 January 2014 Accepted: 12 June 2014

Published: 10 Nov 2014

\section{References}

Acemoglu D, Pischke J: The Structure of Wages and Investment in General Training. J Polit Econ 1999, 107(3):539-572.

Aghion P, Howitt P: Endogenous Growth Theory. Cambridge, MA: MIT press; 1998. MIT Press.

Albert C, García Serrano C, Hernanz V: On-the-job training in Europe: Determinants and wage returns. Int Lab Rev 2010, 149(3):315-341.

Almeida R: Innovation and Openness in East Asia: Have they Increased the Demand for Educated Workers? Asia Pac Dev J 2010, 17(1):63-95.

Almeida RK, Aterido R: Investment in job training: why are SMES lagging so much behind? Policy Research Working Paper Series 5358. Washington, D.C: The World Bank; 2010.

Almeida R, Aterido R: On-the-Job Training and Rigidity of Employment Protection in the Developing World: Evidence from Differential Enforcement. Labour Economics 2011, 18:S71-S82.

Almeida R, Carneiro P: The return to the firm investment in human capital. Lab Econ 2008, 16(2009):97-106. Vol. 44, Issue 5, Pages 701-727.

Almeida R, Cho Y: On-the-job training: Stylized facts and policies around the developing world in Almeida. In The Right skills for the job? Edited by Berhman and Robalino. Washington, D.C: Rethinking training policies in developing countries, World Bank Human Development Perspectives Series, The World Bank; 2012.

Ariga K, Brunello G: Are the More Educated Receiving More Training? Evidence from Thailand. Bonn: IZA Discussion Papers 577, Institute for the Study of Labor (IZA); 2002

Barret A, O'Connell P: Does Training Generally Work? The Returns to In-Company Training. Bonn: Institute for the Study of Labor (IZA); 1999. IZA Discussion Paper No. 51, August 1999.

Bassinini A, Booth A, Brunello G, De Paola M, Leuven E: Workplace Training in Europe. Bonn: Institute for the Study of Labor (IZA); 2005. IZA DP No. 1640.

Becker G: Human Capital. Chicago: The University of Chicago Press; 1964.

Budría S, Pereira P: On the Returns to Training in Portugal. Bonn: Institute for the Study of Labor (IZA); 2004. IZA DP No. 1429.

Chung T: The Returns to Education and Training: Evidence from the Malaysian Family Life Surveys. Kent: University of Kent: 2000. Discussion Paper No. 00/07, University of Kent.

Dearden L, Reed H, Reenen JV: Who Gains When Workers Train? Training and Corporate productivity in a Panel of British Industries. London, UK: The Institute for Fiscal Studies; 2000. WP 00/04.

Dearden L, Reed H, Reenen JV: The Impact of Training on Productivity and Wages: Evidence from British Panel Data, Volume 4. 68th edition. Oxford: Oxford Bulletin of Economics and Statistics, Department of Economics, University of Oxford; 2006:397-421. 08.

Fitzenberger B, Völter R: Long-run effects of training programs for the unemployed in East Germany. Lab Econ 2007, 14(4):730-755.

Frazer G: Learning the Master's Trade: Apprenticeship and Human Capital in Ghana. J Dev Econ 2006, 81(2):259-298.

Haelermans C, Borghans L: Wage Effects of On-the-Job Training: A Meta-Analysis. Br J Ind Relat 2012, 50:502-528. 3 September 2012 0007-1080.

Heckman J, LaLonde RJ, Smith JA: The economics and econometrics of active labour market programs. In Handbook of Labor Economics. Edited by Ashenfelter, Card. North Holland, Amsterdam: New York; 1999:1865-2097.

Johanson R, Wanga G: Skills Training for the Informal Sector in Tanzania. Washington, D.C: World Bank Report; 2008.

Kahyarara G, Teal F: The Returns to Vocational Training and Academic Education: Evidence from Tanzania. World Dev 2008, 36(11):2223-2242.

Leuven E, Oosterbeek H: Firm-specific human capital as a shared investment: Comment. Am Econ Rev 2001, 91:342-347.

Leuven E, Oosterbeek H: A New Approach to Estimate the Wage Returns to Work-Related Training. Bonn: Institute for the Study of Labor (IZA); 2002. IZA DP No. 526.

Leuven E, Oosterbeek H: Evaluating the Effect of Tax deductions on training. J Labor Econ 2004, 22(2):461-488. University of Chicago Press. 
Lillard L, Tan H: Private Sector Training: Who Gets Its and What are its Effects?. Santa Monica: RAND; 1986. RAND Report, R-3331-DOL.

Lopez-Acevedo G, Tan H: Mexico:in-firm Training for the Knowledge Economy. Washington, D.C: World Bank Policy Research Working Paper 2957; 2003.

Lucas R Jr: On the mechanics of economic development. J Monet Econ 1988, 22(1):3-42. Elsevier.

Monk C, Sandefur J, Teal F: Does Doing an Apprenticeship Pay Off? Evidence from Ghana. Oxford: University of Oxford working paper CSAE WPS/2008-08; 2008.

Psacharopoulos G, Patrinos H: Returns to investment in education: a further update. Educ Econ 2004, 12:111-134

Romer P: Endogenous Technological Change. Journal of Political Economy 1990, 98(5):S71-102. University of Chicago Press.

Rosenbaum PR, Rubin DB: The central role of the propensity score in observational studies for casual effects. Biometrika 1983, 70(1):41-55

Rosholm M, Nielsen H, Dabalen A: Evaluation of training in African enterprises. J Dev Econ 2007, 84(2007):310-329.

Sousounis P: The Impact of Work-Related Training on Employee Earnings: Evidence from Great Britain. Munich; 2009. MPRA paper No. 14262

10.1186/2193-9020-3-19

Cite this article as: Almeida and Faria: The wage returns to on-the-job training: evidence from matched employer-employee data. IZA Journal of Labor \& Development 2014, 3:19

Submit your manuscript to a SpringerOpen ${ }^{\circ}$ journal and benefit from:

- Convenient online submission

- Rigorous peer review

- Immediate publication on acceptance

- Open access: articles freely available online

- High visibility within the field

- Retaining the copyright to your article

Submit your next manuscript at $\gg$ springeropen.com 